\title{
Fear, Anger, and Voting for the Far Right: Evidence From the November 13, 2015 Paris Terror Attacks
}

\author{
Pavlos Vasilopoulos \\ Cevipof, Sciences Po \\ George E. Marcus \\ Williams College
}

Nicholas A. Valentino
University of Michigan

Martial Foucault

Cevipof, Sciences Po

\begin{abstract}
The conjecture that negative emotions underpin support for far-right politics is common among pundits and scholars. The conventional account holds that authoritarian populists catalyze public anxiety about the changing social order and/or deteriorating national economic conditions, and this anxiety subsequently drives up support for the far right. We propose that while emotions do indeed play an independent causal role in support for farright parties and policies, that support is more likely built upon the public's anger rather than fear. This article explores the relative impact of fear and anger in reaction to the 2015 Paris terror attacks on the propensity to vote for the French far-right party, the Front National, in the 2015 regional elections. Contrary to conventional wisdom, we find that anger is associated with voting for the Front National, while fear is associated with voting against the Front National. Moreover, anger boosts the Front National vote most powerfully among far-right and authoritarian voters. On the other hand, fear reduces support for the far right among those same groups.
\end{abstract}

KEY WORDS: emotions, France, terrorism, voting

The notion that public support for the far-right springs directly from anxiety is commonplace among journalists, pundits, and scholars. ${ }^{1}$ These public fears, it is often assumed, are triggered by perceived threats from immigration, terrorism, economic insecurity, or some combination (Halikiopoulou, Nanou, \& Vasilopoulou, 2012; Kriesi et al., 2006; Mughan \& Paxton, 2006; Van der Brug \& Fennema, 2007; Werts, Scheepers, \& Lubbers, 1988). These threats, sometimes real but sometimes imagined, become tools for strategic elites. And so, the familiar story goes, far-right

\footnotetext{
${ }^{1}$ Throughout the document, we elect to follow a taxonomy of emotions based on the theory of affective intelligence (Marcus et al., 2000). Therefore, we use both terms, "fear" and "anxiety" interchangeably. People do not seem to discriminate between these two emotions in practice (Rusting \& Larsen, 1995; Watson, Clark, \& Tellegen, 1988). Finally, measures of anxiety and fear load on the same dimension in a factor analysis (see Table A1 in the Appendix).
} 
parties stoke anxiety, especially among authoritarian-minded citizens by presenting economic downturns, cultural change, and both domestic and international security incidents as existential threats.

In this article, we offer an alternative model that focuses on a different emotional substrate, to explain the recent rise in support for the far right in Europe and perhaps elsewhere as well. We propose that it is public anger, rather than anxiety, that motivates support for the far-right vote. While many may indeed react to economic uncertainty, terrorism, and immigration with anxiety, the nature of these threats-often blamed by elites on disliked groups who violate cherished societal norms - is also likely to trigger anger (Banks, 2014; Banks \& Valentino, 2012; Lambert et al., 2010; MacKuen, Wolak, Keele, \& Marcus, 2010; Marcus, Neuman, \& MacKuen, 2000; Valentino, Brader, Groenendyk, Gregorowicz, \& Hutchings, 2011).

Furthermore, affective intelligence theory (AIT) (Marcus et al., 2000, 2002; Marcus, MacKuen, \& Neuman, 2011) and work by various other scholars (Banks, 2014; Banks \& Valentino, 2012; Lambert et al., 2010; Valentino et al., 2011) suggests that increases in anxiety are unlikely to drive support for the far-right vote. On the contrary, voters who experience anxiety in response to threats may be less attracted to the far right. This should also be the case among authoritarians since anxiety inhibits reliance on established predispositions (Marcus et al., 2000).

Our test bed for these hypotheses is the December 2015 French regional elections that took place in the shadow of the Paris attacks. The coordinated November 13 attacks involved shootings and suicide bombings in bars, restaurants, and a concert venue. These constituted the deadliest attacks in France since World War II, leaving 130 dead and 368 people wounded. One day later, ISIS claimed responsibility. If our main conjecture is correct, support for the far-right Front National (FN) in the subsequent election should be highest among those who experienced high levels of anger in response to these attacks, while authoritarians experiencing fear should have been less likely to endorse the FN.

Elections take place every six years to elect regional councilors for each of France's 18 regions. In line with the electoral system for national presidential and legislative elections, they are conducted in two rounds, the second for those instances no candidate received a majority of the vote. The terror events of November 13 occurred just three weeks prior to the first round of nationwide elections for regional offices that took place on December 6, 2015. This conjunction allows us to test the impact of distinct emotional reactions on the propensity to vote for the FN. In the first round of the 2015 regional elections, the FN garnered nearly $28 \%$ of the vote, coming out on top in six out of 13 metropolitan regions. ${ }^{2}$ We obtained measures of how angry and anxious people felt soon after the attacks, allowing us to compare their impact on voting for the FN. We also to explore how the effects of each emotion vary across levels of important political predispositions such as authoritarianism and conservative ideological identification.

Substantial evidence identifies two important dispositional predictors of far-right support: authoritarianism and conservative ideological identification. Individuals supporting authoritarian views those eager to defend social norms and punish rule breakers, are far more likely than others to be FN voters (Vasilopoulos \& Lachat, 2018). Voters who self-identify as ideologically far right are also more inclined to support FN candidates (Lewis-Beck \& Chlarson, 2002; Mayer, 2013; Mayer \& Perrineau, 1992). In addition, those who hold anti-immigration and ethnocentric policy attitudes are quite responsive to FN's electoral appeals (Mayer, 2013, 2014 ). This is hardly surprising, given the salience of anti-immigrant and anti-Islam statements in the party's platform (Stockemer \& Amengay, 2015).

\footnotetext{
${ }^{2}$ In general, due to the French run-off system nonmainstream parties cannot take advantage of the incumbency effect (Golder, Lago, Blais, Gidengil, \& Gschwend, 2017). Specifically, in the case of the FN, the chances of winning a region were further reduced as for the first time in regional elections, the French socialist party decided to withdraw its lists of candidates who had qualified in the second round when it was ranked third or below to prevent the election of FN candidates by supporting the center-right candidates.
} 
An array of sociodemographic factors has been linked to support for far-right leaders, parties, and policies. Support is typically highest among those lowest in education and income (Gougou \& Mayer, 2013; Mayer, 2002, 2014; Perrineau, 1997; Stockemer \& Amengay, 2015). Moreover, perhaps due to its aggressiveness and doctrinal views about gender roles, the FN often performs particularly well among men (Mayer, 2013, 2014 ).

\section{Fear, Anger, and Political Behavior}

Fear and anger are often jointly triggered by different types of social and political threats (MacKuen et al., 2010; Rico, Guinjoan, \& Anduiza, Valentino, Hutchings, Banks, \& Davis, 2008; Vasilopoulou \& Wagner, 2018), including terrorist attacks (Huddy, Feldman, \& Taber, 2005; Lerner, Gonzalez, Small, and Fischhoff 2003; Smith, Rasinski, \& Toce, 2001; Vasilopoulos, 2018; Vasilopoulos, Marcus, \& Foucault, 2018). As we show below, both emotions are experienced by many French citizens in reaction to the attacks. However, each emotion recruits a different psychological process for addressing a threatening target (Marcus, Kinder, MacKuen, Rahn, \& D'Ambrosio, 1995; Marcus, MacKuen, Wolak, \& Keele, 2006).

There are two dominant approaches in the literature regarding the causes of emotional arousal: cognitive appraisal theories and AIT. Cognitive appraisal theories argue that each specific emotions is generated by a specific sequence of evaluations of the environment. For example, if a threat is appraised as stemming from an intentional act by another person, and the target feels she can cope with the threat head on, anger will result (e.g., Carver \& Harmon-Jones, 2009; Frijda, 1986; Lazarus, 1991). When the threat comes from an unfamiliar, uncontrollable source, or one that cannot be overcome, anxiety will dominate (Lazarus, 1991). In other words, standard appraisal theories anticipate that people will report a singular affective state, that is, anger or fear, in response to a given threat.

On the other hand, AIT and subsequent efforts offer a different account of affect. In this theoretical approach, affect is driven by separate, concurrent, but distinct neural systems yielding the expectation that people commonly experience concurrent emotions (Marcus, 2002; MacKuen et al., 2010). Thus, rather than feeling angry or fearful, this perspective expects that it is rather common for people, when facing threat, to experience both anger and fear. That is so because two neural systems are concurrently active. The first of these systems, the primary foci of the original theory, relies on anxiety to signal the extent to which circumstances are unfamiliar or uncertain. Another system relies on enthusiasm to assess the success of habits of thought and actions in securing desired goals. ${ }^{3}$

A third system, appearing in the more recent work both in and outside AIT (Banks \& Valentino, 2012; MacKuen et al., 2010; Valentino et al., 2011), is focused on the presence of threat to familiar norms and practices of thought and action. When cherished group norms and identities are under recurring attack by familiar outgroups, increased anger is generated (indeed this is the principal identifying appraisal of the presence of such threats; see Nitschke, Sarinopoulos, Mackiewicz, Schaefer, \& Davidson, 2006; Phan, Wager, Taylor, \& Liberzon, 2002; Zahn et al., 2013). Anger regulates behavior aimed at securing familiar goals by relying on previously learned routines. However, anxiety helps us identify novelty or uncertainty, and when found, inhibits reliance on prior routines and directs greater attentiveness to and learning about the threat which could facilitate novel behavioral solutions (Albertson \& Gadarian, 2015).

The key insight of AIT is that multiple affective appraisals, of special importance in conditions of threat, anger, and anxiety, occur very soon after the brain begins processing incoming sensory

\footnotetext{
${ }^{3}$ Though unlikely to be pertinent to how the French public might use this third dimension of appraisal in regard to the Paris November attacks, we nonetheless measured enthusiasm. Including this dimension in our various models alters none of the results reported.
} 
and somatosensory signals (Marcus, 2013). These emotions therefore represent preconscious signals in the brain which lead quite automatically to either solidarity and commitment to defend core norms and values (in the case of anger) or decision making more open to contemporary information (in the case of anxiety). Which process dominates depends on which reaction is stronger in the moment. Thus, to understand the impact of how people respond to terror attacks, it is necessary to secure reliable and valid measures of both emotions: anger and anxiety.

AIT and cognitive appraisal theories of emotion both predict similar consequences for both fear and anger in decision making and behavior. Cognitive appraisal theories argue that fearful individuals have a heightened perception of risk and thus engage in risk-aversive strategies vis-à-vis the threatening target (Eysenck, 1992; Lerner \& Keltner, 2001). On the other hand, when it comes to information processing, fear increases attention and boost learning, while anger boosts reliance on cognitive heuristics and stereotypes (Bodenhausen, Sheppard, \& Kramer, 1994; Lerner \& Keltner, 2001).

These behavioral consequences of fear and anger have been illustrated in the realm of political decision making and behavior. Several studies in political psychology that generally align with AIT have found that fear enhances information seeking, making citizens more likely to question their prior habits and become more open to persuasion (Albertson \& Gadarian, 2015; Brader, 2005; Marcus et al., 2000, 2014; Redlawsk, Civettini, \& Emmerson, 2010; Valentino et al., 2008; Vasilopoulos, 2018). One stream of research has found that fear-including fear stemming from terror attacks - increases attention to news and facilitates learning about the threat (Albertson \& Gadarian, 2015; Brader, 2005; Valentino et al., 2008; Vasilopoulos, 2018). Another has shown that fearful voters are less likely to rely on established convictions such as party identification or ideology and instead place more weight on contemporary assessment such as specific political issues or candidates (Brader, 2005; MacKuen, Marcus, Neuman, \& Keele, 2007; Marcus et al., 2000; Vasilopoulos \& Marcus, 2017). Similarly, others have found that fear primes make individuals more likely to reconsider their prior opinions and accept counterarguments coming from ideologically opposed sources (Nai et al., 2017; Redlawsk et al., 2010).

Research in political psychology has shown that anger also impacts political choices: Huddy, Feldman, and Cassese (2007) illustrated that anger decreased individuals' perceived casualty risk of sending troops to fight in Iraq and made individuals more likely to support the war. Banks and Valentino (2012) found that anger caused by a nonpolitical trigger primes racial considerations and, in turn, heightened opposition to redistributive policies such as affirmative action (Banks, 2014). Recently, Rico et al. (2017) found that angry voters were more likely to vote for antiestablishment populist parties, seeking to punish the political status quo. Finally, investigating the impact of emotions on attitudes toward the European Union in the United Kingdom, Vasilopoulou and Wagner (2018) showed that anger was positively associated with support for leaving the EU, while fear was associated with the more moderate option of renegotiating the United Kingdom's relationship with the EU.

Anger also inhibits interest in new political information (MacKuen et al., 2010; Valentino et al., 2008). Moreover, angry individuals tend to discard political information that is discordant with their prior views (MacKuen et al., 2010; Suhay \& Erisen, 2018). As a consequence, anger makes citizens more likely to decide on political issues based on their prior dispositions such as ideology. Vasilopoulos et al. (2018) tested this hypothesis in the aftermath of the Charlie Hebdo attacks in Paris, finding that experiencing anger in the aftermath of the attack increased the impact of rightwing ideology on endorsing authoritarian policies. On the contrary, and in line with the theory of AIT, fear led left-wing individuals to attitude change making them more likely to endorse authoritarian policies. In short, fear decreased, while anger increased the impact of dispositions on political attitudes. Finally, in a recent examination of support for candidate Donald Trump in early 2016, 
(Valentino, Wayne, \& Oceno, 2018) discovered a very similar pattern, with anger boosting and fear suppressing the impact of predispositions like ethnocentrism and sexism.

But though agreeing, in the main, on the downstream effects of fear and of anger, the key difference is that AIT suggests threats elicit two appraisals: Is it novel, and is it noxious? Hence, research on threat compels that both be measured so as to get accurate estimates of the effect of anger and the effect of fear, while holding constant the effects of the other. ${ }^{4}$

Based on the theoretical framework presented above, we hypothesize that fear and anger will have quite different impacts on the propensity to vote for the far right. Conventional wisdom holds that most citizens will respond to terrorist attacks with fear (Albertson \& Gadarian, 2015). A second account holds that those who hold authoritarian attitudes are more likely than others to respond to threat (Feldman \& Stenner, 1997). In addition, this claim has been extended to argue that those who are more conservative, because they are especially sensitive to threat, are also more likely to experience fear which in turn drives support for policies, parties, and leaders that promise security (Hibbing, Smith, \& Alford, 2014; Jost, 2003, 2017). This focus on fearfulness, either as a dispositional sensitivity or as a situational reaction to an imminent threat, has dominated the approach to understanding threat and the political responses generated. ${ }^{5}$

However, if many citizens experience anger in reaction to these attacks, but anger goes unmeasured, we risk misestimating the impact of fear. As our account holds that many people will experience both fearfulness and anger in reaction to a threat, we include measures of both so that we can explore the independent consequences for each. Specifically, we test the following hypotheses.

H1: Anxiety evoked by the attacks should have a negative impact on voting for the FN.

The FN discourse is characterized by a generalized aggressive, vindictive, and exclusionary discourse that is still central to the party communication strategy despite Marine Le Pen's efforts to distance herself from the extreme views of her father and party founder Jean Marie Le Pen (Shields, 2013; Stockemer, 2017). The FN has long advocated aggressive, radical, and previously untested policies such as withdrawing from the EU, returning to a French national currency, minimizing immigration, denying any form of healthcare for illegal immigrants, and targeting Muslims with policies such as lifting the policy that provided Muslim children with lunches that did not contain pork. In the wake of the November 13 attacks, the FN swiftly blamed Muslims and immigrants (despite the French citizenship status of most of the attackers). They proposed aggressive and punitive actions against these groups, such as banning Islamist organizations and shutting mosques. According to the approach we described above, fear evoked by the attacks should make voters more attentive to whether proposals are likely to be successful, that is, they should become more critical. Consequently, we hypothesize that these voters should find less appealing the aggressive and untested policies advocated by the FN.

H2: Anger prompted by the attacks should boost support for the FN.

If the threat is experienced as a familiar assault on cherished values, then the FN, the party long advancing the need to defend nationalist values, will likely be appealing to angry voters. As we

\footnotetext{
${ }^{4}$ There is a further issue, that of misspecification. If cognitive appraisals normally produce a singular "discrete" affective states, or if affective appraisals are simultaneously active, but orthogonal, then the risk of misspecification is modest. But, as we discuss and test below, our theoretical lens leads us to expect that the normal circumstance in facing threat is two concurrent affective appraisals, anger and fear, that are not orthogonal, elevating the risk of misspecification as very substantial if only fear or only anger is studied in isolation.

${ }^{5}$ Two excellent meta-analyses that test these claims (Jost, Nosek, \& Gosling 2008; Jost, Stern, Rule, \& Sterling, 2017) do not consider anger as an independent emotional conduit for support for far-right politics. Since the two emotions are correlated, we suspect that including only fear may have lead to incorrect inferences about the impact of fear.
} 
mentioned above, anger has often been linked to risky, vindictive, and aggressive behavior. This is consistent with our approach as anger, evoked by the Paris terror attacks, signals the need to protect and defend core values. Critically, we will model the impact of fear and anger simultaneously. ${ }^{6}$

But beyond their situational effects (modeled as direct effects), changes in either will also impact the prominent dispositions, though in different ways. This leads to two additional hypotheses.

H3: Fear will reduce the effect of authoritarianism and conservative ideological identification on the propensity to vote for the FN.

As discussed in the theoretical section, this claim follows from the role of anxiety as defined by the theory of AIT and has been confirmed in a number of studies. Past research that has found that increased fear inhibits reliance on dispositions such as ideology or party identification (Brader, 2005; Marcus et al., 2000). Similarly, we anticipate that fear will lessen the impact of authoritarianism and ideological identification on the propensity to vote for the French far right.

Similarly, we expect that anger will also impact the reliance on the relevant dispositions.

H4: Anger will increase reliance on these same dispositions, authoritarianism and conservative ideological identification.

Much as anxiety inhibits reliance on standing patterns of thought and action, anger strengthens reliance on the proven habits of thought and action (Valentino, Gregorowicz, \& Groenendyk, 2009). In sum, and in line with past research reported above, by shifting attention to the contemporary, anxiety should inhibit reliance on otherwise relevant traits (here authoritarianism and conservative ideological identification), reducing their impact on voting for the FN. However, as anger increases reliance on past convictions, angry respondents will find more compelling their long-term psychological dispositions.

\section{Methodology and Data}

The data to test these hypotheses come from the first two waves of the 2017 French Election Study (Enquête Électorale Française), a panel study conducted approximately every month between November 2015 and the French legislative elections in June 2017. The survey was conducted between November 20 and 29, 2015 (Wave 1) and January 22 to February 3, 2016 (Wave 2) using Computer Assisted Web Interviewing (CAWI) in a nationwide sample of 24,369 respondents, 21,555 of which answered both waves. The sample was quota-controlled for age, gender, professional status, and stratified by size of community and region (Ile de France, North- West, North-East, South-West, SouthEast). Sample descriptives are provided in the Appendix. The dependent variable is the reported vote in the first round of the 2015 French regional elections, measured in Wave 2. In the first round of the French regional elections, French citizens voted for a party candidate to serve as the regional councilor. Along with the FN candidates, voters could also choose from among the other three major French political parties, namely the far-left Parti de Gauche ("PdG"), the incumbent center-left Parti Socialiste ("PS"), and the center-right Les Republicains ("LR"). A variety of minor parties were also available (scored as "Other"), as well as a category of those who chose to abstain ("Abstained").

\footnotetext{
${ }^{6}$ The need to do so flows from more than their concurrent activity. They are not expected to be orthogonal and indeed the evidence shows them to be both coactive and highly correlated (Marcus et al., 2006, 2017).

${ }^{7}$ The study was conducted for the Centre de Recherches Politiques de Sciences Po by the polling institute IPSOS MORI and was sponsored by the French Ministry of the Interior.
} 

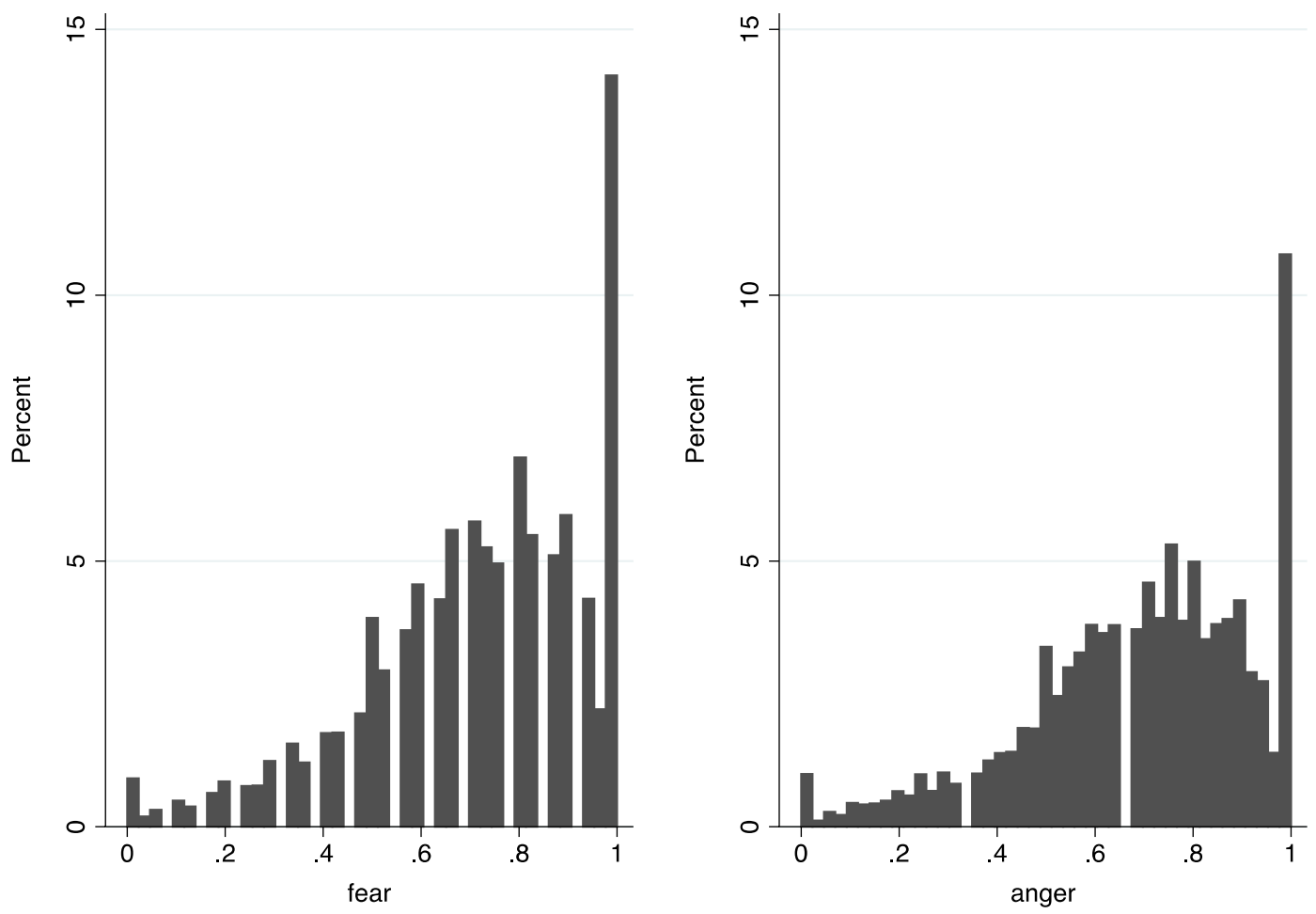

Figure 1. Cojoint emotional reactions to the November 2015 attacks. Source: Enquête électorale française (Wave 1).

[Colour figure can be viewed at wileyonlinelibrary.com]

All of the independent variables were measured in Wave 1. We measure emotional reactions to the terror attacks using the affect terms proposed by Marcus, Neuman, and MacKuen (2017), presented in random order. The level of anxiety/fear is measured with three items, tapping the extent to which respondents felt worried, scared, or fearful when thinking about the November 13 attacks on a scale running from 0 (not at all) to 10 (extremely). ${ }^{8}$ Adding up these three items produces the fear scale (Cronbach's $\alpha=0.82$ ). Anger reactions are measured in a similar way, with items tapping the anger, hatred, bitterness, and resentment respondents felt about the attacks (Cronbach's $\alpha=0.83$ ). ${ }^{9}$ Factor analyses confirmed that the items used to tap fear and anger form two distinct dimensions. ${ }^{10}$ Unsurprisingly, the November attacks evoked very strong emotional reactions in the French population. The two scales are recoded so that they ranged from low (0) to high (1). As shown in Figure 1, the mean of fear is 0.71 and the mean of anger is 0.69 . And, as expected, fear and anger are positively correlated but not multicollinear (Pearson's $r=0.47$ ). ${ }^{11}$ Therefore, as expected, the attacks of

\footnotetext{
${ }^{8}$ The French terms are inquietude, peur, and effroi.

${ }^{9}$ The French terms are colère, haine, amertume, and ressentiment.

${ }^{10}$ See Table A2 in the Appendix. A confirmatory factor analysis, shown in Figure A1 in the Appendix, also supports the same conclusions. The calculated reliabilities for these seven indicators all fall within a narrow and acceptable range, from a low of .72 to a high of .84 .

${ }^{11}$ The Variance Inflation Factor between the two emotional reactions is 1.23 . Since both fear and anger are highly pertinent to threats of any sort, they are strongly positively correlated as numerous studies have shown (Huddy et al., 2007; MacKuen et al., 2010; Marcus et al., 2006; Vasilopoulos, 2018). That is to say, our brains are quickly determining whether immediate circumstances are familiar or not (and reporting the appraisal's results by changing levels of fear) and determining whether core norms are being violated (and reporting those results by changing levels of anger).
} 
November 13 simultaneously elicited anxiety and anger in many respondents. This offers a useful intermediate test of the presumptions made by the cognitive appraisal school that, at any given moment, affective responses are typically singular discrete experiences.

We measure authoritarianism using the child-rearing values scale (Feldman \& Stenner, 1997; see also Federico, Fisher, \& Deason, 2011; Hetherington \& Suhay, 2011; Hetherington \& Weiler, 2009; Stenner, 2005; Vasilopoulos \& Lachat, 2018). The child-rearing values scale asks respondents whether it is more important for a child: (1) to be independent than respectful of his or her grandparents; (2) to have an enquiring mind than to be well mannered; (3) to be well behaved than creative; and (4) to be obedient than autonomous. Ideology has been measured by an item asking respondents to place themselves on a 10-position scale ranging from far left to far right. ${ }^{12}$ Finally, our models include the relevant demographic characteristics to see if those characteristics, here, perform much as they have in prior research. Hence, we include measures for age, gender, social class, and education. All variables are coded to range from 0 to 1 so as to enhance comparability of coefficients and hence of effect size.

\section{Results}

In order to investigate the emotional foundations of support for the FN, we build three models. ${ }^{13}$ In the first, we assess the baseline impact of demographics, authoritarianism, ideology, and fear on the propensity to vote for the FN. This model is our representation of the standard account highlighting the role of fear in response to threats.

Models 2 and 3 elaborates Model 1 by adding anger as a concurrent influence, along with anxiety. In Model 2, we examine the direct influence of anxiety and anger to the terrorist attacks so as to test Hypotheses 1 and 2 (while controlling for the effects of sociodemographic factors). In Model 3, we add four interaction terms to examine the conditional effect of fear and anger with authoritarianism and with right ideological identification on far-right voting. These interactions test the validity of Hypotheses 3 and 4. Since the dependent variable is categorical, we employ multinomial logistic regression. This method is deemed most suitable for analyzing multiparty elections as it allows the comparison of the electoral pool of voters who are drawn to one party (the FN in this case) as against the pool of voters drawn to each of the other parties.

Table 1 displays the results of the first model that includes demographics, self-placement on the left-right scale, authoritarianism, and fear. Entries are multinomial logistic coefficients. Negative coefficients indicate a greater propensity to vote for the FN compared to the party in comparison. For ease of comprehension, parties have been arranged from left to right.

Beginning with the impact of demographics on the propensity to vote for the FN, our findings suggest that in the 2015 French regional election, the far-right party appealed to its typical demographic base consisting of male voters and voters with lower levels of education and lower levels of income compared to voters of the center-left and center-right parties. This is in line with past literature on the demographic correlates of the French far-right vote. Further, the analysis suggests that FN voters place themselves to the right end of the left-right scale, with the effect being statistically significant across all party comparisons. Again, this is consistent with a broad literature on the FN electoral pool and consists of a long-term characteristic of the French far-right voter (Mayer, 2013, 2018; Mayer \& Perrineau, 1992). Finally, and again in line with past research (Vasilopoulos \& Lachat, 2018), the results indicate that authoritarianism runs high among the FN voters, more so than the voters of any other French party.

\footnotetext{
${ }^{12}$ We chose to treat ideology as a continuous variable for simplicity. The analyses have been replicated treating ideology as a categorical variable that includes those who refuse to place themselves on the scale. Results are identical.

${ }^{13}$ As a robustness check, we replicated the analysis adding political attitudes measuring ethnic intolerance. Results are provided in the Appendix.
} 
Table 1. The Standalone Effect of Fear on the Probability to Vote for the FN (full results)

\begin{tabular}{|c|c|c|c|c|c|}
\hline & FDG & PS & Other & LR & Abstained \\
\hline \multicolumn{6}{|l|}{ Dispositional } \\
\hline \multirow[t]{2}{*}{ Left-Right scale } & $-14.02^{* *}$ & $-10.11^{* *}$ & $-6.72^{* *}$ & $-1.35^{* *}$ & $-5.57^{* *}$ \\
\hline & $(0.31)$ & $(0.16)$ & $(0.14)$ & $(0.12)$ & $(0.14)$ \\
\hline \multirow[t]{2}{*}{ Authoritarianism } & $-1.52^{* *}$ & $-0.92^{* *}$ & $-0.97^{* *}$ & $-0.65^{* *}$ & $-0.72^{* *}$ \\
\hline & $(0.16)$ & $(0.09)$ & $(0.09)$ & $(0.08)$ & $(0.09)$ \\
\hline \multicolumn{6}{|l|}{ Situational } \\
\hline \multirow[t]{2}{*}{ Fear } & $-0.62^{* *}$ & -0.17 & $-0.59^{* *}$ & 0.00 & $-0.26^{*}$ \\
\hline & $(0.21)$ & $(0.12)$ & $(0.12)$ & $(0.11)$ & $(0.12)$ \\
\hline \multicolumn{6}{|l|}{ Demographics } \\
\hline \multirow[t]{2}{*}{ Age } & 0.17 & -0.28 & -0.43 & $0.80^{* *}$ & $-2.34^{* *}$ \\
\hline & $(0.46)$ & $(0.25)$ & $(0.24)$ & $(0.22)$ & $(0.24)$ \\
\hline \multirow[t]{2}{*}{ Female } & -0.00 & $0.43^{* *}$ & $0.35^{* *}$ & $0.39^{* *}$ & $0.52^{* *}$ \\
\hline & $(0.11)$ & $(0.06)$ & $(0.06)$ & $(0.05)$ & $(0.06)$ \\
\hline \multirow[t]{2}{*}{ Income } & $0.05^{* *}$ & $0.06^{* *}$ & 0.00 & $0.06^{* *}$ & -0.01 \\
\hline & $(0.02)$ & $(0.01)$ & $(0.01)$ & $(0.01)$ & $(0.01)$ \\
\hline \multirow[t]{2}{*}{ Middle education } & $0.64^{* *}$ & $0.22 *$ & $0.27^{* *}$ & $0.29^{* *}$ & 0.05 \\
\hline & $(0.16)$ & $(0.09)$ & $(0.08)$ & $(0.07)$ & $(0.08)$ \\
\hline \multirow[t]{2}{*}{ High education } & $0.52^{* *}$ & $0.59^{* *}$ & $0.66^{* *}$ & $0.79^{* *}$ & $0.32^{* *}$ \\
\hline & $(0.16)$ & $(0.08)$ & $(0.08)$ & $(0.07)$ & $(0.08)$ \\
\hline \multirow[t]{2}{*}{ Farmers } & -13.97 & 0.25 & 0.44 & 0.14 & 0.18 \\
\hline & $(701.80)$ & $(0.33)$ & $(0.29)$ & $(0.29)$ & $(0.30)$ \\
\hline \multirow[t]{2}{*}{ Self-employed } & -0.24 & -0.01 & 0.26 & $0.41^{* *}$ & $0.30 *$ \\
\hline & $(0.39)$ & $(0.18)$ & $(0.15)$ & $(0.13)$ & $(0.15)$ \\
\hline \multirow[t]{2}{*}{ Managers } & $0.55^{* *}$ & $0.71^{* *}$ & $0.47^{* *}$ & $0.61^{* *}$ & $0.35^{* *}$ \\
\hline & $(0.20)$ & $(0.10)$ & $(0.10)$ & $(0.09)$ & $(0.10)$ \\
\hline \multirow[t]{2}{*}{ Midlevel professionals } & $0.57^{* *}$ & $0.31^{* *}$ & $0.35^{* *}$ & $0.21^{* *}$ & $0.21^{*}$ \\
\hline & $(0.17)$ & $(0.09)$ & $(0.09)$ & $(0.08)$ & $(0.09)$ \\
\hline \multirow[t]{2}{*}{ Manual workers } & 0.10 & 0.03 & -0.02 & -0.13 & 0.14 \\
\hline & $(0.22)$ & $(0.12)$ & $(0.12)$ & $(0.11)$ & $(0.11)$ \\
\hline \multirow[t]{2}{*}{ Pensioners } & $0.60^{* *}$ & $0.63^{* *}$ & $0.37^{* *}$ & $0.51^{* *}$ & $0.28^{* *}$ \\
\hline & $(0.19)$ & $(0.10)$ & $(0.10)$ & $(0.09)$ & $(0.10)$ \\
\hline \multirow[t]{2}{*}{ Other nonlabor } & 0.28 & $0.22 *$ & $0.26^{* *}$ & $0.21^{*}$ & $0.18^{*}$ \\
\hline & $(0.19)$ & $(0.10)$ & $(0.09)$ & $(0.09)$ & $(0.09)$ \\
\hline \multirow[t]{2}{*}{ Constant } & $4.52^{* *}$ & $4.95^{* *}$ & $4.26^{* *}$ & $-0.50^{* *}$ & $4.30^{* *}$ \\
\hline & $(0.37)$ & $(0.21)$ & $(0.20)$ & $(0.19)$ & $(0.20)$ \\
\hline Observations & 20,013 & 20,013 & 20,013 & 20,013 & 20,013 \\
\hline Pseudo $\mathrm{R}^{2}$ & 0.17 & & & & \\
\hline
\end{tabular}

Note. Table entries are unstandardized multinomial logistic regression coefficients (with their standard errors in parentheses). The base outcome is voting for the FN. Negative coefficients indicate an increase in the probability of voting for the FN, while positive coefficients suggest an increase in the probability of voting for the other party in comparison. The reference group in social class is clerical and service staff.

Source: Enquête électorale française. ${ }^{*} p<0.05 ;{ }^{*} p<0.01$. 
Table 2. The Standalone Effect of Fear and Anger on the Probability to Vote for the FN (full results)

\begin{tabular}{|c|c|c|c|c|c|}
\hline & FDG & PS & Other & LR & Abstained \\
\hline \multicolumn{6}{|l|}{ Dispositional } \\
\hline \multirow[t]{2}{*}{ Left-Right scale } & $-13.69^{* *}$ & $-9.78^{* *}$ & $-6.39^{* *}$ & $-0.98^{* *}$ & $-5.27^{* *}$ \\
\hline & $(0.31)$ & $(0.16)$ & $(0.14)$ & $(0.12)$ & $(0.14)$ \\
\hline \multirow[t]{2}{*}{ Authoritarianism } & $-1.40^{* *}$ & $-0.79^{* *}$ & $-0.87^{* *}$ & $-0.55^{* *}$ & $-0.63^{* *}$ \\
\hline & $(0.17)$ & $(0.09)$ & $(0.09)$ & $(0.08)$ & $(0.09)$ \\
\hline \multicolumn{6}{|l|}{ Situational } \\
\hline \multirow[t]{2}{*}{ Fear } & 0.25 & $0.75^{* *}$ & 0.21 & $0.79^{* * *}$ & $0.43^{* *}$ \\
\hline & $(0.24)$ & $(0.14)$ & $(0.13)$ & $(0.12)$ & $(0.14)$ \\
\hline \multirow[t]{2}{*}{ Anger } & $-2.23^{* *}$ & $-2.36^{* *}$ & $-2.08^{* *}$ & $-2.12^{* *}$ & $-1.85^{* *}$ \\
\hline & $(0.25)$ & $(0.15)$ & $(0.15)$ & $(0.14)$ & $(0.15)$ \\
\hline \multicolumn{6}{|l|}{ Demographics } \\
\hline \multirow[t]{2}{*}{ Age } & 0.45 & 0.01 & -0.17 & $1.05^{* *}$ & $-2.12^{* *}$ \\
\hline & $(0.47)$ & $(0.25)$ & $(0.24)$ & $(0.22)$ & $(0.24)$ \\
\hline \multirow[t]{2}{*}{ Female } & -0.07 & $0.36^{* *}$ & $0.29^{* *}$ & $0.33^{* *}$ & $0.47^{* *}$ \\
\hline & $(0.11)$ & $(0.06)$ & $(0.06)$ & $(0.05)$ & $(0.06)$ \\
\hline \multirow[t]{2}{*}{ Income } & $0.05^{* *}$ & $0.06^{* *}$ & 0.01 & $0.06^{* *}$ & -0.00 \\
\hline & $(0.02)$ & $(0.01)$ & $(0.01)$ & $(0.01)$ & $(0.01)$ \\
\hline \multirow[t]{2}{*}{ Middle education } & $0.62^{* *}$ & $0.20^{*}$ & $0.25^{* *}$ & $0.28^{* *}$ & 0.04 \\
\hline & $(0.16)$ & $(0.09)$ & $(0.08)$ & $(0.07)$ & $(0.08)$ \\
\hline \multirow[t]{2}{*}{ High education } & $0.45^{* *}$ & $0.52^{* *}$ & $0.60^{* *}$ & $0.75^{* *}$ & $0.28^{* *}$ \\
\hline & $(0.16)$ & $(0.08)$ & $(0.08)$ & $(0.07)$ & $(0.08)$ \\
\hline \multirow[t]{2}{*}{ Farmers } & -14.05 & 0.17 & 0.38 & 0.09 & 0.12 \\
\hline & (704.93) & $(0.33)$ & $(0.29)$ & $(0.29)$ & $(0.30)$ \\
\hline \multirow[t]{2}{*}{ Self-employed } & -0.25 & -0.03 & 0.24 & $0.39^{* *}$ & 0.29 \\
\hline & $(0.39)$ & $(0.18)$ & $(0.16)$ & $(0.13)$ & $(0.15)$ \\
\hline \multirow[t]{2}{*}{ Managers } & $0.49 *$ & $0.65^{* *}$ & $0.43^{* *}$ & $0.56^{* *}$ & $0.31^{* *}$ \\
\hline & $(0.20)$ & $(0.10)$ & $(0.10)$ & $(0.09)$ & $(0.10)$ \\
\hline \multirow[t]{2}{*}{ Midlevel professionals } & $0.54^{* *}$ & $0.28^{* *}$ & $0.33^{* *}$ & $0.19^{*}$ & $0.19 *$ \\
\hline & $(0.17)$ & $(0.09)$ & $(0.09)$ & $(0.08)$ & $(0.09)$ \\
\hline \multirow[t]{2}{*}{ Manual workers } & 0.10 & 0.03 & -0.02 & -0.13 & 0.14 \\
\hline & $(0.22)$ & $(0.12)$ & $(0.12)$ & $(0.11)$ & $(0.11)$ \\
\hline \multirow[t]{2}{*}{ Pensioners } & $0.61^{* *}$ & $0.65^{* *}$ & $0.38^{* *}$ & $0.52^{* *}$ & $0.29^{* *}$ \\
\hline & $(0.19)$ & $(0.10)$ & $(0.10)$ & $(0.09)$ & $(0.10)$ \\
\hline \multirow[t]{2}{*}{ Other nonlabor } & 0.32 & $0.26^{* *}$ & $0.29^{* *}$ & $0.24^{* *}$ & $0.21^{*}$ \\
\hline & $(0.19)$ & $(0.10)$ & $(0.09)$ & $(0.09)$ & $(0.09)$ \\
\hline \multirow[t]{2}{*}{ Constant } & $5.17^{* *}$ & $5.63^{* *}$ & $4.87^{* *}$ & 0.11 & $4.86^{* *}$ \\
\hline & $(0.37)$ & $(0.22)$ & $(0.21)$ & $(0.19)$ & $(0.21)$ \\
\hline Observations & & & 20,013 & & \\
\hline Pseudo $\mathrm{R}^{2}$ & 0.18 & & & & \\
\hline
\end{tabular}

Note. Table entries are unstandardized multinomial logistic regression coefficients (with their standard errors in parentheses). The base outcome is voting for the FN. Negative coefficients indicate an increase in the probability of voting for the FN, while positive coefficients suggest an increase in the probability of voting for the other party in comparison. The reference group in social class is clerical and service staff.

Source: Enquête électorale française. ${ }^{*} p<0.05 ;{ }^{* *} p<0.01$. 

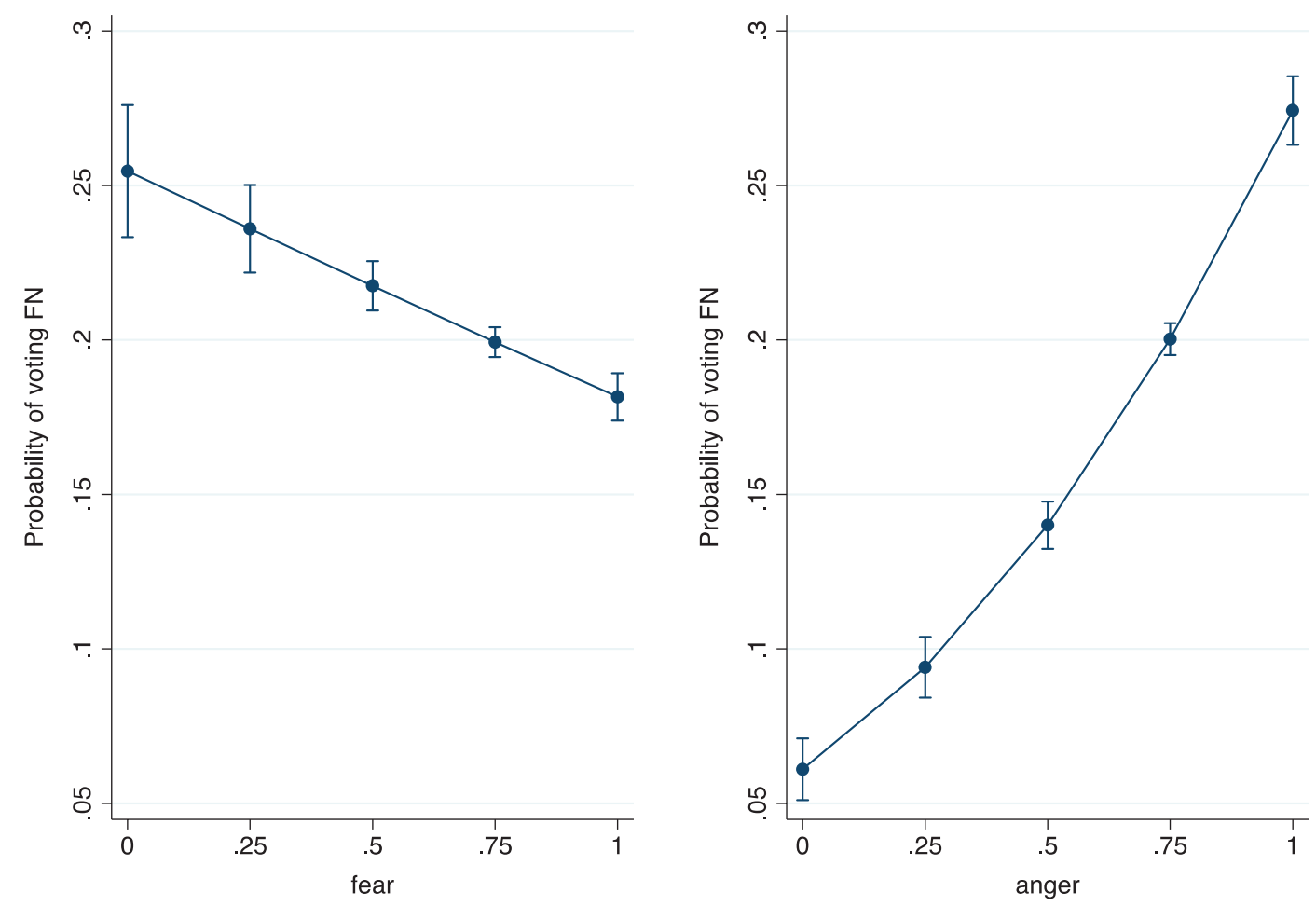

Figure 2. The direct effect of fear and anger on the probability of voting for the FN. Source: Enquête électorale française. [Colour figure can be viewed at wileyonlinelibrary.com]

To this point, we have shown that in the 2015 French Regional elections the FN appealed to its typical electorate consisting of low socioeconomic status and authoritarian voters who place themselves on the far right. These results affirm the influence of long-term dispositional factors that identify the kinds of voters more prone to voting for the far right. How do situational appraisals, however, impact far-right voting? The results from Model 1 suggest that when anger is omitted, fear in reaction to the attacks does seem to increase the propensity to vote for the FN. This pattern seems to confirm conventional wisdom that fear increases the likelihood of casting a vote for the FN, compared to the far-left FDG, minor parties, and even compared to abstaining altogether. However, as reported in the theoretical section, given that fear and anger correlate, and anger has different behavioral qualities compared to fear, we believe omitting anger is a serious misspecification.

Table 2 includes all the variables included in the first analysis (Table 1), but it importantly adds anger to the model. The results confirm Hypotheses 1 and 2. Incorporating anger in the analysis, we find that fear reduces the likelihood of an FN vote compared to the center-left PS, the center-right LR, and even compared to abstaining altogether. This confirms our first hypothesis. However, anger in response to the attacks powerfully increased the propensity to vote for the French far right compared to all other parties and to abstaining in the 2015 Regional elections. This is fully in line with our second hypothesis. Further, the effect of anger is similar across different electoral groups, with the exception of abstainers where it is slightly weakened. This is in line with past research over the positive effect of anger on political participation in the light of the Paris terror attacks (Vasilopoulos, 2018). The associations of fear and anger with the propensity to vote for the FN are displayed in Figure 2. The 

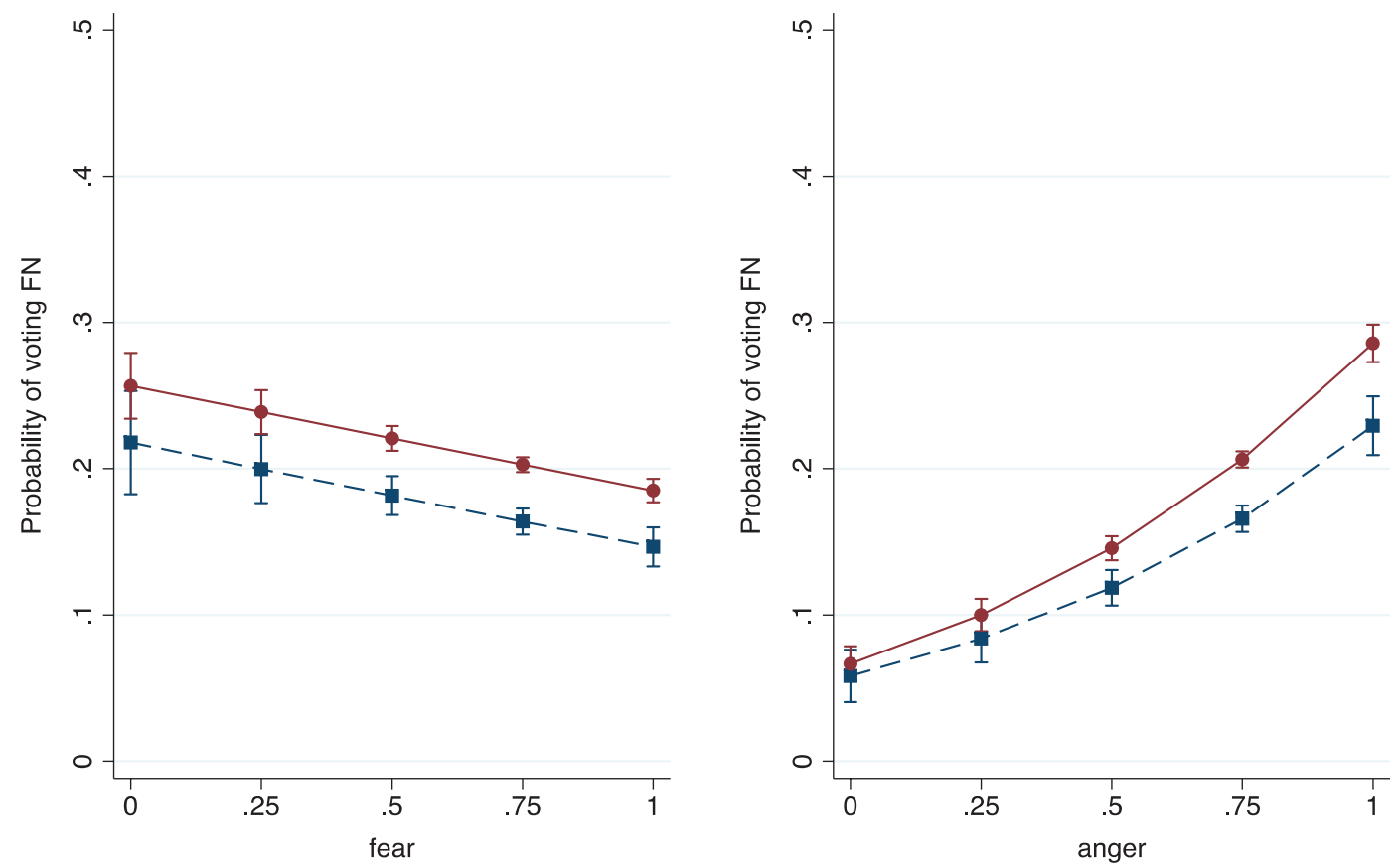

$--\mathbf{- 1}-$ low authoritarianism $(0.25)$

high authoritarianism $(0.75)$

Figure 3. The impact of authoritarianism on the probability of voting for the FN at different levels of fear and anger. Source: Enquête électorale française. [Colour figure can be viewed at wileyonlinelibrary.com]

figure clearly illustrates the strong and contrary associations between the two emotional reactions and voting for the far right. Furthermore, Figure 2 suggests that the effect of fear and especially anger robustly alters the propensity to vote for the FN.

We next turn to the interactive effects of emotions and predispositions-authoritarianism and conservative ideological identification - on support for the FN. Our third hypothesis leads us to anticipate that fear will reduce the impact of both authoritarianism and conservative ideological identification on the propensity to vote for the FN. Our fourth hypothesis anticipates that experiencing anger will increase the impact of the same dispositions on voting for the far right. Interaction coefficients, on their own, are insufficient as the significance of the coefficients is only weakly related to the substantive effects of interest (Brambor, Clarke, \& Golder, 2006). Hence, we present two marginal effects plots, Figures 3 and 4, to illustrate the impact of authoritarianism and ideology on the probability of voting for the French far right at different levels of fear and anger. These results represent tests of the third and fourth hypotheses respectively. ${ }^{14}$ The regression models on which these figures are based are presented in the Appendix.

Overall, the results in Figure 3 confirm Hypotheses 3 and 4. The left side of Figure 3 reveals that fear reduces support for the FN among respondents who score high in authoritarianism. The rightside panel of Figure 3 shows the effect of anger. Among respondents high in authoritarianism, anger in response to the attacks increases support for the FN. As we expect, the effect of anger is smaller among nonauthoritarian voters. This is as we predicted: People who do not subscribe to authoritarian

\footnotetext{
${ }^{14}$ Following Berry et al. (2012), we also estimated the effect of ideology at different levels of fear and anger (Figures A3 and A4 in the Appendix). Results confirm our expectations: Anger increases, while fear decreases the effect of authoritarianism and ideology on the probability of voting for the FN.
} 

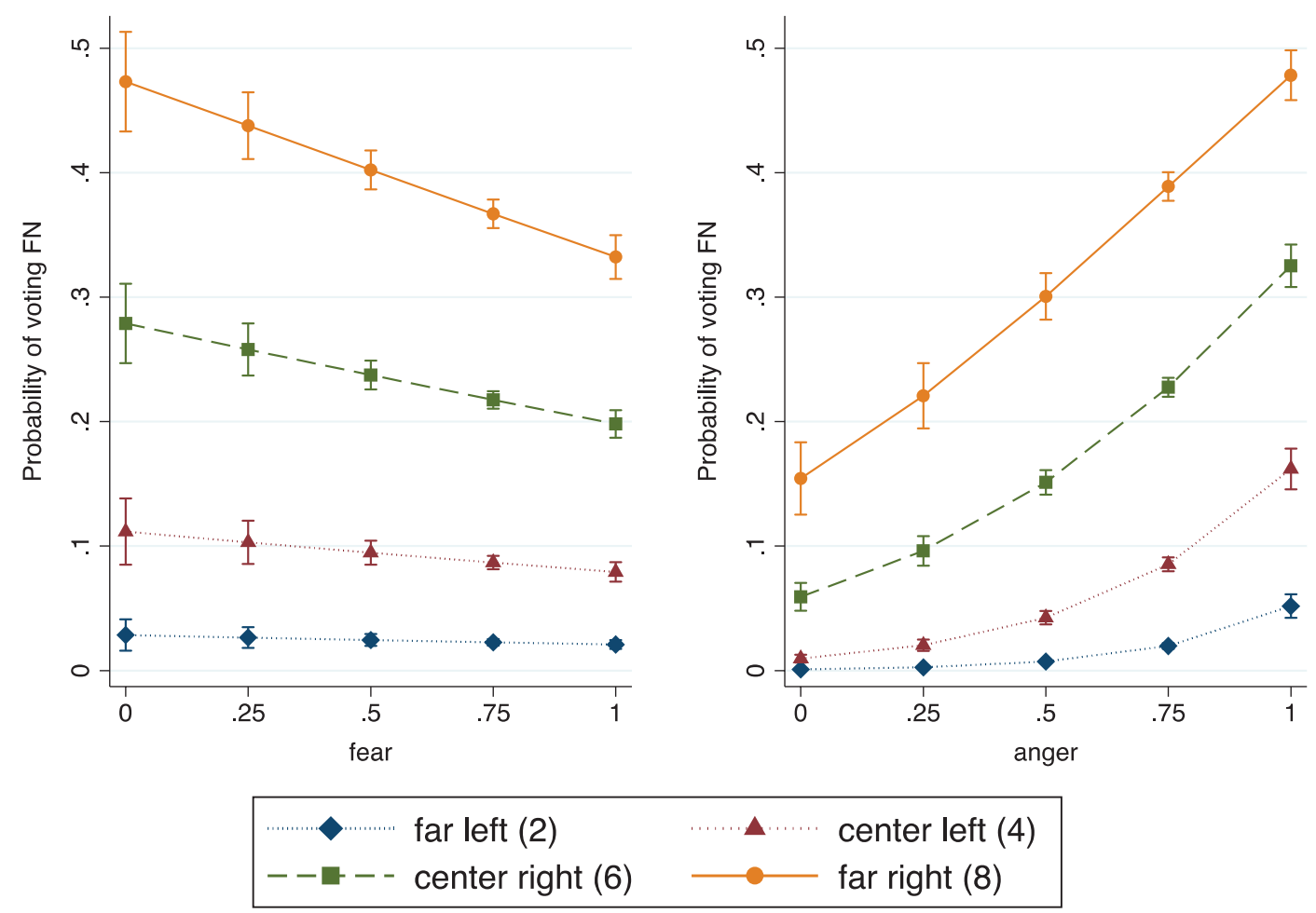

Figure 4. The impact of different ideological self-placements on the probability of voting for the FN at different levels of fear and anger. Source: Enquête électorale française. [Colour figure can be viewed at wileyonlinelibrary.com]

values should be less likely to become mobilized for the far right even if they experience anger in reaction to the attacks.

The distinct conditioning effects of these emotional reactions are even larger when we examine the interaction of the two situational affective appraisals on the influence of conservative ideological identification. Figure 4 replicates the presentation shown in Figure 3. The interaction results are displayed for four groups of voters: those who place themselves in the far left (position 2 on the 10-point, left-right scale), center left (position 4 on the left-right scale), center right (position 6 on the left-right scale), and far-right (position 8 on the left-right scale). The figure shows that as fear increases, far-right respondents become less likely to vote for the FN. The same is the case with center-right supporters, although the effect is not as strong, while fear does not make any difference among those who place themselves in the center or the far left. However, anger boosts support for the FN among all voters, but especially among those who place themselves on the right end of the ideology scale. All in all, ideology has the highest impact on the FN vote at the maximum value of anger. It is noteworthy that angry center-left respondents have the same probability of voting for the FN as nonangry far-right respondents.

These results confirm Hypotheses 3 and 4. Increased anger strengthens reliance on both dispositions, authoritarianism and conservative ideological identification. To the contrary, increased fear reduces reliance on both dispositions. We consider the implications of these findings next. 


\section{Conclusion}

Popular and scholarly attention to the rise of far-right authoritarian parties has long focused on the role of anxiety as the critical psychological causal mechanism. The rise of the far right is frequently attributed to the careful deployment of anxiety by charismatic politicians, often by scapegoating oppressed minority groups. Conventional wisdom holds that threats generate a singular appraisal: Is this threat substantial? The answer is thought to be found in increased levels of fear. That is indeed a useful question. But it is not the only pertinent question.

Our interpretation of the theory of AIT leads us to expect that threats are examined by two different pertinent questions. One appraisal considers whether this threat is novel. The answer is given by increasing anxiety when that appraisal is positive. When the answer is yes, then stored habits are not likely to secure the expected outcomes that those habits have previously secured. In as much as reliance on habits in novel circumstances would likely prove inefficacious, greater anxiety inhibits reliance on those habits of thought and action and initiates a search for pertinent information, among them being the character of the threat and what options and what alliances are most promising (Albertson \& Gadarian, 2015; MacKuen et al., 2010). The other concurrent question is: Does this threat challenge valued norms and values, marked by increased anger? If the answer is yes, then the habitual defensive routines are marshaled, and partisan solidarity is strengthened (Valentino et al., 2011).

We tested this approach to terror threat in this study. We analyzed the distinct impacts of fear and anger on voting for the French far right in the elections held just weeks after the 2015 French terror attacks. Our results suggest a new explanation for far-right voting. While both anger and fear appeals are common in far-right discourse, our results show that anger evoked by the terrorist attacks has the far stronger and positive impact on support for the far right, while anxiety weakens support for far-right voting. Further, our results also show that these two affective reactions each interact with dispositional traits but in different ways. Anger strengthens the role of the convictions that align with far-right voting. Anxiety, however, weakens the influence of the dispositional convictions that encourage voting for the far right.

Our results suggest that once fear is evoked, it leads to a reassessment of supporting dispositions by inhibiting this otherwise automatic propensity to vote for the far right. ${ }^{15}$ Right-wing identifiers and authoritarians are also likely to experience increased anger. And once anger kicks in, it strengthens the public's reliance on dispositional traits, boosting their probability of voting for the far right. In this sense, the findings of this study provide an explanatory framework for understanding political polarization (Bartels, 2000; Iyengar et al., 2012). To the extent that anger dominates the political landscape, among those all along the ideological spectrum, polarization is likely to be made more evident, as each ideological tribe advances the rightness of its convictions with greater fervor. Our findings, however, suggest that when fear ascends, citizens will tend to rely less on their disposition, and will become more attentive to political issues and the actual attributes of the candidates. Thus, anxious citizens will become less partisan in their vote choices (MacKuen et al., 2007).

A recent stream of research has shown that citizens experience heightened fear and anger in response to threats other than terrorism. These include economic conditions (Rico et al., 2017; Wagner, 2017), their country's membership in supranational political institutions such as the EU (Vasilopoulou \& Wagner, 2018), legislative acts (Valentino \& Neuer, 2017), media content (MacKuen et al., 2010; Marcus et al., 2018) or politicians (Marcus et al., 1993, 2000; Ragsdale, 1991). Other research has illustrated that fear and anger stemming from stimuli unrelated to politics also shape political decision making (Banks, 2014; Banks \& Valentino, 2012). Consequently, we anticipate that the findings of this study may well be generalized in contexts other than terrorist threat. More generally, our results

\footnotetext{
${ }^{15}$ We use the term "automatic" in the sense that Bargh and colleagues $(1992,1999)$ apply, that is to say fast, unreflexive reliance on established habits.
} 
are in line with a growing literature that demonstrates the differential effects of fear and anger in political behavior (MacKuen et al., 2010; Valentino et al., 2011, 2008; Vasilopoulos, 2018; Vasilopoulos et al., 2018; Wagner, 2017). Further, they provide evidence on the distinct behavioral effects of fear and anger on political behavior from a European setting, illustrating that affect has similar political consequences across contexts (see also Erisen, 2013; Vasilopoulos, 2018; Vasilopoulos et al., 2018; Wagner, 2017). Overall, these findings highlight the need to include measures both of anger and anxiety in the study of the association between threat and the endorsement of different facets of the conservative and authoritarian ideologies (Feldman \& Stenner, 1997; Hetherington \& Suhay, 2011; Jost et al., 2017; Jost, Glaser, Kruglanski, \& Sulloway, 2003).

If we turn our attention to theoretical models that guide scholars, we can build on these insights to derive other implications. As politics, especially democratic politics, is inherently combativereflecting the natural clashing of social, private interests, and the differing visions of the public interest - then this duality of anger and anxiety is likely common. The thrust of this work points to a need for a new theoretical formulation that more fully captures the distinct affects of anger and fear. Rather than focusing on the usefulness of emotion as directing the search for information, as the theory of AIT has done, we see a more expansive role for emotion, that of animating the human capacity for agency, though of two kinds. Much of the interest in emotion in political science, psychology, and political psychology has focused on information gathering, both at the outset (Marcus \& MacKuen, 1993) and since (Albertson \& Gadarian, 2015; Cheung-Blunden \& Ju, 2016). Therefore, we propose the theory of affective agency to accommodate the core insight that information of all sorts, affective and semantic, serves human agency.

The intention of this theoretical perspective is to identify how affective processes prepare people to act. Our focus expands beyond information gathering to explore how some situational affective appraisals strengthen reliance on habituated pattern of action, while other concurrent affective situational appraisals diminish reliance thereupon for, instead, reflexive consideration of the circumstances, the available options for action, allegiance, and purpose. In sum, emotion, as Hume (1984) famously asserted, "Reason is, and ought only to be the slave of the passions, and can never pretend to any other office than to serve and obey them" (p. 462). That observation may turn out to be both perspicuous but also lead to a more optimistic result for politics than is commonly thought.

\section{ACKNOWLEDGMENTS}

The authors would like to thank Serge Galam, John Jost, Nonna Mayer, the participants of the 2016 American Political Science Association conference, the participants of the seminar of the political science department at the University of Texas A\&M, and the participants of the seminar of the Amsterdam Institute for Social Science Research for their useful comments in earlier versions of the article. The authors thank the USPC (Université Sorbonne Paris Cité) - Sciences Po, University Paris Descartes, and University Paris Diderot) for financial support provided to principal investigator (Martial Foucault) on the project "Emotions, Voting, Attitudes, and Radicalism." Correspondence concerning this article should be addressed to George E. Marcus, P. O. Box 595, Williamstown, MA 01267. E-mail: gmarcus@williams.edu

\section{REFERENCES}

Albertson, B., \& Gadarian, S. K. (2015). Anxious politics: Democratic citizenship in a threatening world. New York, NY: Cambridge University Press.

Banks, A. J. (2014). Anger and racial politics: The emotional foundation of racial attitudes in America. Cambridge, United Kingdom: Cambridge University Press. 
Banks, A. J., \& Valentino, N. A. (2012). Emotional substrates of White racial attitudes. American Journal of Political Science, 56, 286-297.

Bargh, J. A., Chaiken, S., Govender, R., \& Pratto, F. (1992). The generality of the automatic attitude activation effect. Journal of Personality and Social Psychology, 62(6), 893-912.

Bargh, J. A., \& Chartrand, T. L. (1999). The unbearable automaticity of being. American Psychologist, 54(7), 462-479.

Bartels, L. M. (2000). Partisanship and voting behavior, 1952-1996. American Journal of Political Science, 44(1), 35-50.

Berry, W. D., Golder, M., \& Milton, D. (2012). Improving tests of theories positing interaction. Journal of Politics, 74(3), 653-671.

Bodenhausen, G. V., Sheppard, L. A., \& Kramer, G. P. (1994). Negative affect and social judgment: The differential impact of anger and sadness. European Journal of Social Psychology, 24, 45-62.

Brader, T. (2005). Striking a responsive chord: How political ads motivate and persuade voters by appealing to emotions. American Journal of Political Science, 49, 388-405.

Brambor, T., Clark, W. R., \& Golder, M. (2006). Understanding interaction models: Improving empirical analyses. Political Analysis, 14, 63-82.

Carver, C. S., \& Harmon-Jones, E. (2009). Anger is an approach-related affect: Evidence and implications. Psychological Bulletin, 135, 183-204.

Cheung-Blunden, V., \& Ju, J. (2016). Anxiety as a barrier to information processing in the event of a cyberattack. Political Psychology, 37(3), 387-400.

Erisen, C. (2013). Emotions as a determinant in Turkish political behavior. Turkish Studies, 14(1), 115-135.

Eysenck, M. W. (1992). Anxiety: The cognitive perspective. London, United Kingdom: Lawrence-Erlbaum.

Federico, C. M., Fisher, E. L., \& Deason, G. (2011). Political expertise and the link between the authoritarian predisposition and conservatism. Public Opinion Quarterly, 75, 686-708.

Feldman, S., \& Stenner, K. (1997). Perceived threat and authoritarianism. Political Psychology, 18, 741-770.

Frijda, N. H. (1986). The emotions. Cambridge, United Kingdom: Cambridge University Press.

Golder, S. N., Lago, I., Blais, A., Gidengil, E., \& Gschwend, T. (2017). Multi-level electoral politics: Beyond the second-order election model. Oxford, United Kingdom: Oxford University Press.

Gougou, F., \& Mayer, N. (2013). The class basis of extreme right voting in France: Generational replacement and the rise of new cultural issues (1984-2007). In J. Rydgren (Ed.), Class politics and the radical right (pp. 156-172). London, United Kingdom: Routledge.

Halikiopoulou, D., Nanou, K., \& Vasilopoulou, S. (2012). The paradox of nationalism: The common denominator of radical right and radical left Euroscepticism. European Journal of Political Research, 51, 504-539.

Hetherington, M., \& Suhay, E. (2011). Authoritarianism, threat, and Americans' support for the war on terror. American Journal of Political Science, 55, 546-560.

Hetherington, M. J., \& Weiler, J. D. (2009). Authoritarianism and polarization in American politics. Cambridge, United Kingdom: Cambridge University Press.

Hibbing, J. R., Smith, K. B., \& Alford, J. R. (2014). Differences in negativity bias underlie variations in political ideology. Behavioral and Brain Research, 37(3), 297-350.

Huddy, L., Feldman, F., \& Cassese, E. (2007). On the distinct political effects of anxiety and anger. In G. E. Marcus, W. Russell Neuman, M. MacKuen, \& A. N. Crigler (Eds.), The affect effect: Dynamics of emotion in political thinking and behavior (pp. 202-230). Chicago, IL: Chicago Scholarship Online.

Huddy, L., Feldman, S., Taber, C., \& Lahav, G. (2005). Threat, anxiety, and support of antiterrorism policies. American Journal of Political Science, 49, 593-608.

Hume, D. (1984). A treatise of human nature. London, United Kingdom: Penguin Books.

Iyengar, S., Sood, G., \& Lelkes, Y. (2012). Affect, not ideology: A social identity perspective on polarization. Pubic Opinion Quarterly, 76(3), 405-431.

Jost, J. T., Glaser, J., Kruglanski, A. W., \& Sulloway, F. J. (2003). Political conservatism as motivated social cognition. Psychological Bulletin, 129, 339-375.

Jost, J. T., Nosek, B. A., \& Gosling, S. D. (2008). Ideology: Its resurgence in social, personality, and political psychology. Perspectives on Psychological Science, 3, 126-136.

Jost, J. T., Stern, C., Rule, N. O., \& Sterling, J. (2017). The politics of fear: Is there an ideological assymmetry in existential motivation? Social Cognition, 35(4), 324-353.

Kriesi, H., Grande, E., Lachat, R., Dolezal, M., Bornschier, S., \& Frey, T. (2006). Globalization and the transformation of the national political space: Six European countries compared. European Journal of Political Research, 45, 921-956.

Lambert, A. J., Scherer, L. D., Schott, J. P., Olson, K. R., Andrews, R. K., O’Brien, T. C., \& Zisser, A. R. (2010). Rally effects, threat, and attitude change: An integrative approach to understanding the role of emotion. Journal of Personality and Social Psychology, 98(6), 886-903.

Lazarus, R. S. (1991). Emotion and adaptation. Oxford, United Kingdom: Oxford University Press.

Lerner, J. S., Gonzalez, R. M., Small, D. A., \& Fischhoff, B. (2003). Effects of fear and anger on perceived risks of terrorism a national field experiment. Psychological Science, 14, 144-150.

Lerner, J. S., \& Keltner, D. (2001). Fear, anger, and risk. Journal of Personality and Social Psychology, 81, $146-159$.

Lewis-Beck, M. S., \& Chlarson, K. (2002). Party, ideology, institutions and the 1995 French presidential election. British Journal of Political Science, 32, 489-512.

MacKuen, M., Marcus, G. E., Russell Neuman, W., \& Keele, L. (2007). The third way: The theory of affective intelligence and American democracy. In G. E. Marcus, W. Russell Neuman, M. MacKuen, \& A. N. Crigler (Eds.), The affect effect: Dynamics of emotion in political thinking and behavior (pp. 124-151). Chicago, IL: Chicago Scholarship Online. 
MacKuen, M., Wolak, J., Keele, L., \& Marcus, G. E. (2010). Civic engagements: Resolute partisanship or reflective deliberation. American Journal of Political Science, 54, 440-458.

Marcus, G. E. (2002). The sentimental citizen: Emotion in democratic politics. University Park: Pennsylvania State University Press.

Marcus, G. E. (2013). Political psychology: Neuroscience, genetics and politics. New York, NY: Oxford University Press.

Marcus, G. E., Kinder, D. R., MacKuen, M., Rahn, W., \& D’Ambrosio, L. (1995). Measuring emotional response in the 1995 pilot: A proposal to the 1995 NES Pilot Planning Committee. National Election Studies Board of Overseers.

Marcus, G. E., \& MacKuen, M. B. (1993). Anxiety, enthusiasm and the vote: The emotional underpinnings of learning and involvement during presidential campaigns. American Political Science Review, 87(3), 688-701.

Marcus, G. E., MacKuen, M., \& Neuman, W. R. (2011). Parsimony and complexity: Developing and testing theories of affective intelligence. Political Psychology, 32(2), 323-336.

Marcus, G. E., MacKuen, M., Wolak, J., \& Keele, L. (2006). The measure and mismeasure of emotion. In D. Redlawsk (Ed.), Feeling politics: Emotion in political information processing (pp. 31-46). New York, NY: Palgrave Macmillan.

Marcus, G. E., Neuman, W. R., \& MacKuen, M. (2000). Affective intelligence and political judgment. Chicago, IL: University of Chicago Press.

Marcus, G. E., Neuman, W. R., \& MacKuen, M. (2014). Ideology, affect, context, and political judgment: When conservatives and liberals share feelings and when they don't. Paper presented at the 2014 annual meeting of the American Political Science Association. Washington DC.

Marcus, G. E., Neuman, W. R., \& MacKuen, M. B. (2017). Measuring emotional response: Comparing alternative approaches to measurement. Political Science Research and Methods, 5(4), 733-754.

Mayer, N. (2002). Ces français qui votent Le Pen. Paris, France: Flammarion.

Mayer, N. (2013). From Jean-Marie to Marine Le Pen: Electoral change on the far right. Parliamentary Affairs, 66, $160-178$. Mayer, N. (2014). The electoral impact of the crisis on the French working class: More to the Right? In N. Bermeo \& L. Bartels (Eds.), Mass politics in tough times (pp. 266-296). Oxford, United Kingdom: Oxford University Press.

Mayer, N. (2018). The radical right in France. In J. Rydgren (Ed.), The Oxford handbook of the radical right (pp. 433-451). Oxford, United Kingdom: Oxford University Press.

Mayer, N., \& Perrineau, P. (1992). Why do they vote for Le Pen? European Journal of Political Research, 22, 123-141.

Mughan, A., \& Paxton, P. (2006). Anti-immigrant sentiment, policy preferences and populist party voting in Australia. British Journal of Political Science, 36, 341-358.

Nai, A., Schemeil, Y., \& Marie, J.-L. (2017). Anxiety, sophistication, and resistance to persuasion: Evidence from a quasi-experimental survey on global climate change. Political Psychology, 38(1), 137-156.

Nitschke, J. B., Sarinopoulos, I., Mackiewicz, K. L., Schaefer, H. S., \& Davidson, R. J. (2006). Functional neuroanatomy of aversion and its anticipation. NeuroImage, 29, 106-116.

Perrineau, P. (1997). Le symptôme Le Pen. Radiographie des électeurs du Front national. Paris, France: Fayard.

Phan, K. L., Wager, T., Taylor, S. F., \& Liberzon, I. (2002). Functional neuroanatomy of emotion: A meta-analysis of emotion activation studies in PET and fMRI. Neurolmage, 16(2), 331-348.

Ragsdale, L. (1991). Strong feelings: Emotional responses to presidents. Political Behavior, 13(1), 33-65.

Redlawsk, D. P., Civettini, A., \& Emmerson, K. M. (2010). The affective tipping point: Do motivated reasoners ever get it? Political Psychology, 31, 563-593.

Rico, G., Guinjoan, M., \& Anduiza, E. (2017). The emotional underpinnings of populism: How anger and fear affect populist attitudes. Swiss Political Science Review, 23(4), 44-46.

Rusting, C. L., \& Larsen, R. L. (1995). Moods as sources of stimulation: Relationships between personality and desired mood states. Personality and Individual Differences, 18(3), 321-329.

Shields, J. (2013). Marine Le Pen and the "new" FN: A change of style or of substance? Parliamentary Affairs, 66(1), $179-196$.

Smith, T. W., Rasinski, K. A., \& Toce, M. (2001). America rebounds: A national study of public response to the September 11th terrorist attacks. Chicago, IL: National Opinion Research Center at the University of Chicago.

Stenner, K. (2005). The authoritarian dynamic. Cambridge, United Kingdom: Cambridge University Press.

Stockemer, D., \& Amengay, A. (2015). The voters of the FN under Jean-Marie Le Pen and Marine Le Pen: Continuity or change French. Politics, 13, 370-390.

Stockemer, D., \& Barisione, M. (2017). The "new" discourse of the Front National under Marine Le Pen: A slight change with a big impact. European Journal of Communication, 32(2), 100-115.

Suhay, E., \& Erisen, C. (2018). The role of anger in the biased assimilation of political information. Political Psychology. doi:https://doi.org/10.1111/pops.12463

Valentino, N. A., Brader, T., Groenendyk, E. W., Gregorowicz, K., \& Hutchings, V. L. (2011). Election night's alright for fighting: The role of emotions in political participation. Journal of Politics, 73, 156-170.

Valentino, N. A., Gregorowicz, K., \& Groenendyk, E. (2009). Efficacy, emotions and the habit of participation. Political Behavior, 31, 307-330.

Valentino, N. A., Hutchings, V. L., Banks, A. J., \& Davis, A. K. (2008). Is a worried citizen a good citizen? Emotions, political information seeking, and learning via the internet. Political Psychology, 29, 247-273.

Valentino, N. A., Wayne, C., \& Oceno, M. (2018). Mobilizing sexism: The interaction of emotion and gender attitudes in the 2016 US presidential election. Public Opinion Quarterly, 82(1), 213-235.

Valentino, N. A., \& Neuner, F. G. (2017). Why the sky didn't fall: Mobilizing anger in reaction to voter ID laws. Political Psychology, 38(2), 331-350.

Van der Brug, W., \& Fennema, M. (2007). Causes of voting for the radical right. International Journal of Public Opinion Research, 19(4), 474-487. 
Vasilopoulos, P. (2018). Terrorist events, emotional reactions, and political participation: The 2015 Paris attacks. West European Politics, 41(1), 102-127.

Vasilopoulos, P., \& Lachat, R. (2018). Authoritarianism and electoral choice in France. Acta Politica 53(4), $612-634$.

Vasilopoulos, P., \& Marcus, G. E. (2017). Deux voies vers la droite. In O. Filleule, F. Haegel, C. Hamidi, \& V. Tiberj (Eds.), Sociologie plurielle des comportements politiques (pp. 289-320). Paris, France: Presses de Sciences Po.

Vasilopoulos, P., Marcus, G. E., \& Foucault, M. (2018). Emotional responses to the Charlie Hebdo attacks: Addressing the authoritarianism puzzle. Political Psychology, 39(3), 557-575.

Vasilopoulou, S., \& Wagner, M. (2017). Fear, anger and enthusiasm about the European Union: Effects of emotional reactions on public preferences towards European integration. European Union Politics, 18(3), 382-405.

Wagner, M. (2014). Fear and anger in Great Britain: Blame assignment and emotional reactions to the financial crisis. Political Behavior, 36(3), 683-703.

Werts, H., Scheepers, P., \& Lubbers, M. (2013). Euro-scepticism and radical right-wing voting in Europe, 2002-2008: Social cleavages, socio-political attitudes and contextual characteristics determining voting for the radical right European Union. Politics, 14, 183-205.

Zahn, R., Moll, J., Paiva, M., Garrido, G., Krueger, F., Huey, E. D., \& Grafman, J. (2009). The neural basis of human social values: Evidence from Functional MRI. Cerebral Cortex, 19(2), 176-283. 


\section{APPENDIX}

Table A1. Comparisons Between the Sample, the French Census, and the Results of the 2012 French Presidential Election

\begin{tabular}{|c|c|c|c|c|c|c|c|c|}
\hline & & $\begin{array}{l}\text { Difference } \\
\text { between } \\
\text { sample } \\
\text { and } \\
\text { census }\end{array}$ & & & $\begin{array}{l}\text { Difference } \\
\text { between } \\
\text { sample and } \\
\text { census }\end{array}$ & & & $\begin{array}{l}\text { Difference } \\
\text { between } \\
\text { sample and } \\
\text { the } 2012 \\
\text { French } \\
\text { Presidential } \\
\text { election } \\
\text { results }\end{array}$ \\
\hline \multirow[t]{10}{*}{$\begin{array}{l}\text { Gender } \mathrm{x} \\
\text { Age }\end{array}$} & Men / 18-24 & -0.5 & Region & Île-de-France & 0.7 & $\begin{array}{l}\text { Vote in the First } \\
\text { round of the } \\
2012 \text { French } \\
\text { Presidential } \\
\text { Election }\end{array}$ & N. Arthaud & -0.1 \\
\hline & Men / 25-34 & -1.6 & & Centre Val de Loire & 0.4 & & P. Poutou & -0.1 \\
\hline & Men / 35-49 & 1.1 & & $\begin{array}{l}\text { Bourgogne } \\
\text { France-Comté }\end{array}$ & -0.1 & & JL. Melenchon & -2 \\
\hline & Men / 50-64 & -0.2 & & Normandie & -0.4 & & F. Hollande & 2.9 \\
\hline & Men / $65+$ & -2.6 & & $\begin{array}{l}\text { Nord Pas-de-Calais } \\
\text { Picardie }\end{array}$ & 0.6 & & E. Jolly & 0.8 \\
\hline & $\begin{array}{c}\text { Women / } \\
18-24\end{array}$ & 0.7 & & $\begin{array}{l}\text { Alsace Champagne- } \\
\text { Ardenne Lorraine }\end{array}$ & 0.3 & & F. Bayrou & 0.7 \\
\hline & $\begin{array}{r}\text { Women / } \\
25-34\end{array}$ & 2 & & Pays de la Loire & 0.8 & & N. Sarkozy & -0.3 \\
\hline & $\begin{array}{c}\text { Women / } \\
35-49\end{array}$ & 4 & & Bretagne & 0.4 & & $\begin{array}{l}\text { N. } \\
\text { Dupont- } \\
\text { Aignan }\end{array}$ & 0.3 \\
\hline & $\begin{array}{r}\text { Women / } \\
50-64\end{array}$ & 1.5 & & $\begin{array}{l}\text { Aquitaine Limousin } \\
\text { Poitou-Charentes }\end{array}$ & -1 & & M. Le Pen & -1.6 \\
\hline & Women / $65+$ & -4.4 & & $\begin{array}{l}\text { Languedoc- } \\
\text { Roussillon } \\
\text { Midi-Pyrénées }\end{array}$ & -0.8 & & & \\
\hline \multirow[t]{8}{*}{$\begin{array}{l}\text { Social } \\
\text { Class }\end{array}$} & Farmers & -1 & & $\begin{array}{l}\text { Auvergne } \\
\text { Rhône-Alpes }\end{array}$ & 0.2 & & & \\
\hline & $\begin{array}{l}\text { Independent } \\
\text { profession- } \\
\text { als }\end{array}$ & -0.6 & & $\begin{array}{c}\text { Provence-Alpes- } \\
\text { Côte d'Azur }\end{array}$ & -1.3 & & & \\
\hline & Managers & 4.2 & $\begin{array}{l}\text { Level of } \\
\text { education }\end{array}$ & No diploma & -19.1 & & & \\
\hline & $\begin{array}{l}\text { Intermediate } \\
\text { professions }\end{array}$ & 4.2 & & BEPC, CAP, BEP & -7.3 & & & \\
\hline & Employees & 4.2 & & Bac. & 1.7 & & & \\
\hline & Workers & -5 & & $\begin{array}{l}\text { High education } \\
\text { degree }\end{array}$ & 24.7 & & & \\
\hline & Retired & -6.9 & & & & & & \\
\hline & Inactive & 0.9 & & & & & & \\
\hline
\end{tabular}


Table A2. Coding and Wording of Authoritarianism and Ethnic Intolerance Items Authoritarianism

\begin{tabular}{ll}
\hline Query & Response Options \\
\hline It is more important for a child to be independent & 1 . Be independent \\
or respectful of his/her parents or grandparents? & 2 . Be respectful of his/her grandparents \\
It is more important for a child to have an enquiring & 1 . Have an enquiring mind \\
mind or be well-mannered? & 2 . Be well mannered \\
It is more important for a child to be wellbehaved & 1. Be well behaved \\
$\quad$ or creative? & 2. Be creative \\
It is more important for a child to be obedient & 1. Be obedient \\
$\quad$ than autonomous? & 2. Be autonomous \\
\hline
\end{tabular}

Source: Enquête électorale française

Table A3. Rotated Factor Loadings of the Fear and Anger Dimensions

\begin{tabular}{lll}
\hline & Factor 1 & Factor 2 \\
\hline Worry (inquietude) & & 0.78 \\
Fear (peur) & & 0.81 \\
Fright (effroi) & 0.71 & 0.66 \\
Bitterness (amertume) & 0.70 & \\
Anger (colère) & 0.78 & \\
Resentment (ressentiment) & 0.70 & \\
Hatred (haine) & 0.79 & 0.72 \\
Variance proportion &
\end{tabular}

Note. Oblique rotation (promax). Only factor loadings over 0.3 are shown. 


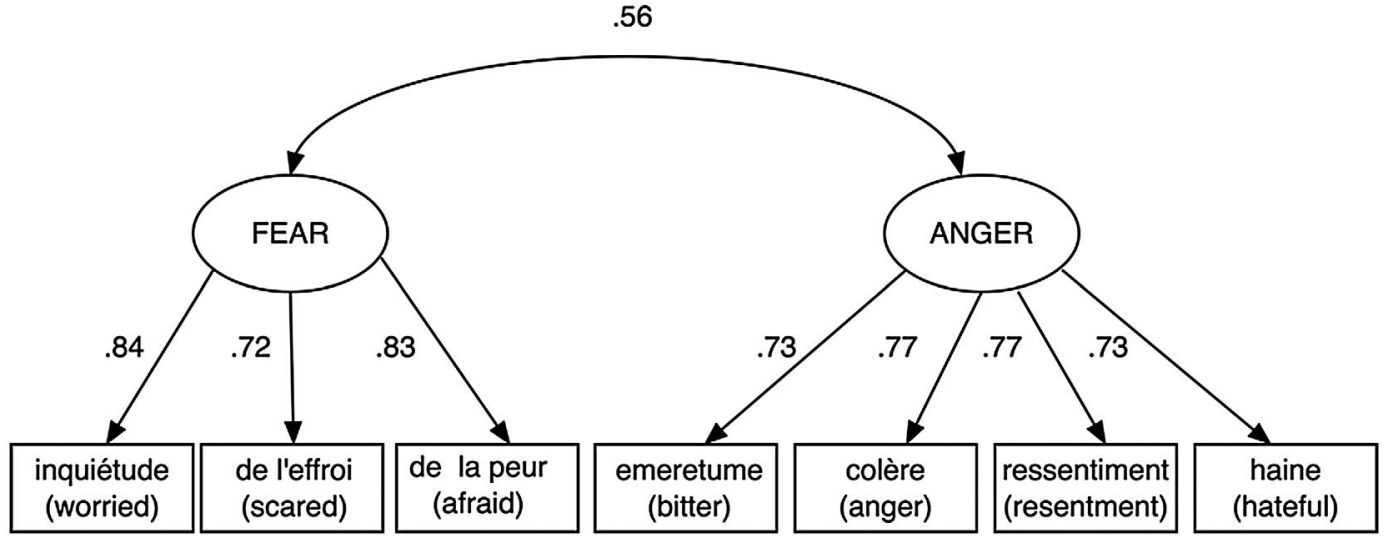

SEM Model of Fear and Anger Dimensions

Figure A1. Confirmatory factor analysis of the emotional reactions to the November 13 attacks. $N=24,325 ; \chi 2(13$ $d f)=1840.52, p>\operatorname{chi} 2=0.0001 ;$ RMSEA $=0.076 ; \mathrm{CFI}=0.976 ;$ SMSR $=0.032$. A single-factor solution, that is a single latent factor (Negative Affect) with all seven indicators treated as measuring this one latent factor does not fit the data. $\chi^{2}$ $(14 d f)=19359.82, p>$ chi2 $=0.0001 ;$ RMSEA $=0.238 ; \mathrm{CFI}=0.741 ; \mathrm{SMSR}=0.114$. Source Enquête électorale française.

Table A4. Interactive Model: The Indirect Effect of Fear and Anger Along Ideology and Authoritarianism on the Probability to Vote for the FN

\begin{tabular}{|c|c|c|c|c|c|}
\hline & FDG & PS & Other & LR & Abstained \\
\hline \multicolumn{6}{|l|}{ Dispositional } \\
\hline \multirow[t]{2}{*}{ Left-Right scale } & $-19.29^{* *}$ & $-13.15^{* *}$ & $-11.43^{* *}$ & $-2.02^{* *}$ & $-8.90^{* *}$ \\
\hline & $(1.10)$ & $(0.68)$ & $(0.63)$ & $(0.56)$ & $(0.63)$ \\
\hline \multirow[t]{2}{*}{ Authoritarianism } & -0.68 & -0.04 & $-0.91^{*}$ & -0.04 & $-0.90^{*}$ \\
\hline & $(0.56)$ & $(0.38)$ & $(0.37)$ & $(0.36)$ & $(0.38)$ \\
\hline \multicolumn{6}{|l|}{ Situational } \\
\hline \multirow[t]{2}{*}{ Fear } & -0.70 & 0.77 & -0.06 & 0.43 & 0.51 \\
\hline & $(0.66)$ & $(0.51)$ & $(0.50)$ & $(0.49)$ & $(0.51)$ \\
\hline \multirow[t]{2}{*}{ Anger } & $-4.15^{* *}$ & $-4.47^{* *}$ & $-5.64^{* *}$ & $-2.17^{* *}$ & $-5.11^{* *}$ \\
\hline & $(0.72)$ & $(0.59)$ & $(0.58)$ & $(0.56)$ & $(0.59)$ \\
\hline \multicolumn{6}{|l|}{ Dispositional $\times$ Situational } \\
\hline \multirow[t]{2}{*}{ Left-Right scale $\times$ Fear } & $4.12^{* *}$ & 0.45 & 0.41 & 0.59 & -0.16 \\
\hline & $(1.45)$ & $(0.77)$ & $(0.68)$ & $(0.60)$ & $(0.69)$ \\
\hline \multirow[t]{2}{*}{ Left-Right scale $\times$ Anger } & $3.35^{*}$ & $3.80^{* *}$ & $6.31^{* *}$ & 0.58 & $4.87^{* *}$ \\
\hline & $(1.48)$ & $(0.86)$ & $(0.80)$ & $(0.71)$ & $(0.80)$ \\
\hline \multirow[t]{2}{*}{ Authoritarianism $\times$ Fear } & -0.05 & -0.53 & 0.02 & -0.08 & -0.10 \\
\hline & $(0.74)$ & $(0.45)$ & $(0.43)$ & $(0.41)$ & $(0.45)$ \\
\hline \multirow[t]{2}{*}{ Authoritarianism $\times$ Anger } & -1.01 & -0.57 & 0.13 & -0.64 & 0.56 \\
\hline & $(0.79)$ & $(0.51)$ & $(0.50)$ & $(0.47)$ & $(0.51)$ \\
\hline \multicolumn{6}{|l|}{ Demographics } \\
\hline \multirow[t]{2}{*}{ Age } & 0.44 & 0.01 & -0.19 & $1.07^{* *}$ & $-2.14^{* *}$ \\
\hline & $(0.47)$ & $(0.25)$ & $(0.24)$ & $(0.22)$ & $(0.24)$ \\
\hline
\end{tabular}




\begin{tabular}{|c|c|c|c|c|c|}
\hline & FDG & PS & Other & LR & Abstained \\
\hline \multirow[t]{2}{*}{ Female } & -0.08 & $0.36^{* *}$ & $0.29^{* *}$ & $0.33^{* *}$ & $0.47^{* *}$ \\
\hline & $(0.11)$ & $(0.06)$ & $(0.06)$ & $(0.05)$ & $(0.06)$ \\
\hline \multirow[t]{2}{*}{ Income } & $0.05^{* *}$ & $0.06^{* *}$ & 0.01 & $0.06^{* *}$ & -0.00 \\
\hline & $(0.02)$ & $(0.01)$ & $(0.01)$ & $(0.01)$ & $(0.01)$ \\
\hline \multirow[t]{2}{*}{ Middle education } & $0.59^{* *}$ & $0.18^{*}$ & $0.24^{* *}$ & $0.28^{* *}$ & 0.03 \\
\hline & $(0.16)$ & $(0.09)$ & $(0.08)$ & $(0.07)$ & $(0.08)$ \\
\hline \multirow[t]{2}{*}{ High education } & $0.43^{* *}$ & $0.50^{* *}$ & $0.59^{* *}$ & $0.75^{* *}$ & $0.26^{* *}$ \\
\hline & $(0.16)$ & $(0.08)$ & $(0.08)$ & $(0.07)$ & $(0.08)$ \\
\hline \multirow[t]{2}{*}{ Farmers } & -14.33 & 0.18 & 0.37 & 0.10 & 0.12 \\
\hline & $(815.37)$ & $(0.33)$ & $(0.29)$ & $(0.29)$ & $(0.31)$ \\
\hline \multirow[t]{2}{*}{ Self-employed } & -0.23 & -0.01 & 0.26 & $0.40^{* *}$ & $0.30^{*}$ \\
\hline & $(0.39)$ & $(0.18)$ & $(0.16)$ & $(0.13)$ & $(0.15)$ \\
\hline \multirow[t]{2}{*}{ Managers } & $0.51^{* *}$ & $0.66^{* *}$ & $0.43^{* *}$ & $0.56^{* *}$ & $0.30^{* *}$ \\
\hline & $(0.20)$ & $(0.10)$ & $(0.10)$ & $(0.09)$ & $(0.10)$ \\
\hline \multirow[t]{2}{*}{ Mid-level professionals } & $0.55^{* *}$ & $0.28^{* *}$ & $0.33^{* *}$ & $0.19^{*}$ & $0.18^{*}$ \\
\hline & $(0.17)$ & $(0.09)$ & (0.09) & $(0.08)$ & $(0.09)$ \\
\hline \multirow[t]{2}{*}{ Manual workers } & 0.11 & 0.02 & -0.03 & -0.13 & 0.14 \\
\hline & $(0.23)$ & $(0.12)$ & $(0.12)$ & $(0.11)$ & $(0.11)$ \\
\hline \multirow[t]{2}{*}{ Pensioners } & $0.63^{* *}$ & $0.65^{* *}$ & $0.38^{* *}$ & $0.53^{* *}$ & $0.29^{* *}$ \\
\hline & $(0.19)$ & $(0.10)$ & $(0.10)$ & $(0.09)$ & $(0.10)$ \\
\hline \multirow[t]{2}{*}{ Other nonlabor force } & 0.34 & $0.26^{* *}$ & $0.29^{* *}$ & $0.24^{* *}$ & $0.21^{*}$ \\
\hline & $(0.19)$ & $(0.10)$ & $(0.09)$ & $(0.09)$ & $(0.09)$ \\
\hline \multirow[t]{2}{*}{ Constant } & $7.43^{* *}$ & $7.36^{* *}$ & $7.71^{* *}$ & 0.54 & $7.25^{* *}$ \\
\hline & $(0.61)$ & $(0.48)$ & $(0.47)$ & $(0.46)$ & $(0.48)$ \\
\hline Observations Pseudo $\mathrm{R}^{2}$ & 0.18 & & 20,013 & & \\
\hline
\end{tabular}

Note. Table entries are unstandardized multinomial logistic regression coefficients (with their standard errors in parentheses). The base outcome is voting for the FN. Negative coefficients indicate an increase in the probability of voting for the FN, while positive coefficients suggest an increase in the probability of voting for the other party in comparison. The reference group in social class is clerical and service staff. ${ }^{*} p<0.05{ }^{* *} p<0.01$.

Source: Enquête électorale française 


\section{Robustness Check}

We construct a scale of ethnic intolerance from five items: "there are too many immigrants in France"; "Islam is a threat to the West"; "French natives should have priority in employment compared to foreigners"; "immigration is a source of cultural enrichment"; and, "Children of immigrants born in France are as French as anyone else." Each of these items is measured with 5-point Likert scales while the last two items are reverse scored. The Cronbach's alpha for the five items is 0.88 .

Table A5. Robustness Test

\begin{tabular}{|c|c|c|c|c|c|}
\hline & FDG & PS & Other & LR & Abstained \\
\hline \multicolumn{6}{|l|}{ Political Attitudes } \\
\hline \multirow[t]{2}{*}{ Ethnic intolerance } & $-6.57^{* *}$ & $-6.60^{* *}$ & $-5.37^{* *}$ & $-5.27^{* *}$ & $-4.70^{* *}$ \\
\hline & $(0.27)$ & $(0.16)$ & $(0.16)$ & $(0.15)$ & $(0.16)$ \\
\hline \multicolumn{6}{|l|}{ Dispositional } \\
\hline \multirow[t]{2}{*}{ Authoritarianism } & $-0.64^{* *}$ & -0.04 & $-0.30^{* *}$ & 0.00 & -0.14 \\
\hline & $(0.17)$ & $(0.10)$ & $(0.10)$ & $(0.09)$ & $(0.10)$ \\
\hline \multirow[t]{2}{*}{ Left-right scale } & $-11.89^{* *}$ & $-7.93^{* *}$ & $-4.92^{* *}$ & $0.56^{* *}$ & $-4.02^{* *}$ \\
\hline & $(0.31)$ & $(0.16)$ & $(0.15)$ & $(0.14)$ & $(0.15)$ \\
\hline \multicolumn{6}{|l|}{ Situational } \\
\hline \multirow[t]{2}{*}{ Fear } & 0.13 & $0.63^{* *}$ & 0.07 & $0.65^{* *}$ & $0.29^{*}$ \\
\hline & $(0.25)$ & $(0.15)$ & $(0.14)$ & $(0.13)$ & $(0.14)$ \\
\hline \multirow[t]{2}{*}{ Anger } & -0.47 & $-0.60^{* *}$ & $-0.66^{* *}$ & $-0.77^{* *}$ & $-0.62^{* *}$ \\
\hline & $(0.26)$ & $(0.16)$ & $(0.16)$ & $(0.15)$ & $(0.16)$ \\
\hline \multicolumn{6}{|l|}{ Demographics } \\
\hline \multirow[t]{2}{*}{ Age } & $1.04^{*}$ & $0.58^{*}$ & 0.23 & $1.42^{* *}$ & $-1.79^{* *}$ \\
\hline & $(0.47)$ & $(0.26)$ & $(0.25)$ & $(0.23)$ & $(0.25)$ \\
\hline \multirow[t]{2}{*}{ Female } & -0.13 & $0.30^{* *}$ & $0.25^{* *}$ & $0.30^{* *}$ & $0.43^{* *}$ \\
\hline & $(0.11)$ & $(0.06)$ & $(0.06)$ & $(0.05)$ & $(0.06)$ \\
\hline \multirow[t]{2}{*}{ Income } & $0.04^{*}$ & $0.05^{* *}$ & -0.00 & $0.06^{* *}$ & -0.01 \\
\hline & $(0.02)$ & $(0.01)$ & $(0.01)$ & $(0.01)$ & $(0.01)$ \\
\hline \multirow[t]{2}{*}{ Middle education } & $0.56^{* *}$ & 0.14 & $0.24^{* *}$ & $0.29^{* *}$ & 0.04 \\
\hline & $(0.16)$ & (0.09) & $(0.09)$ & $(0.08)$ & $(0.09)$ \\
\hline \multirow[t]{2}{*}{ High education } & 0.25 & $0.33^{* *}$ & $0.51^{* *}$ & $0.71^{* *}$ & $0.22^{* *}$ \\
\hline & $(0.16)$ & $(0.09)$ & $(0.08)$ & $(0.07)$ & $(0.08)$ \\
\hline \multirow[t]{2}{*}{ Farmers } & -14.21 & 0.17 & 0.35 & 0.06 & 0.09 \\
\hline & $(763.46)$ & $(0.34)$ & $(0.30)$ & $(0.30)$ & $(0.31)$ \\
\hline \multirow[t]{2}{*}{ Self-employed } & -0.27 & -0.03 & 0.28 & $0.45^{* *}$ & $0.34^{*}$ \\
\hline & $(0.40)$ & $(0.19)$ & $(0.16)$ & $(0.14)$ & $(0.16)$ \\
\hline \multirow[t]{2}{*}{ Managers } & 0.34 & $0.50^{* *}$ & $0.33^{* *}$ & $0.49^{* *}$ & $0.24^{*}$ \\
\hline & $(0.20)$ & $(0.11)$ & $(0.11)$ & $(0.10)$ & $(0.11)$ \\
\hline \multirow[t]{2}{*}{ Midlevel professionals } & $0.41^{*}$ & 0.15 & $0.24^{* *}$ & 0.11 & 0.11 \\
\hline & $(0.17)$ & $(0.10)$ & $(0.09)$ & $(0.08)$ & $(0.09)$ \\
\hline \multirow[t]{2}{*}{ Manual workers } & 0.11 & 0.04 & -0.00 & -0.11 & 0.15 \\
\hline & $(0.23)$ & $(0.13)$ & $(0.12)$ & $(0.12)$ & $(0.12)$ \\
\hline \multirow[t]{2}{*}{ Pensioners } & $0.57^{* *}$ & $0.63^{* *}$ & $0.38^{* *}$ & $0.54^{* *}$ & $0.29^{* *}$ \\
\hline & $(0.19)$ & $(0.11)$ & $(0.10)$ & (0.09) & $(0.11)$ \\
\hline
\end{tabular}




\begin{tabular}{llllll}
\hline & FDG & PS & Other & LR & Abstained \\
\hline Other non-labor force & 0.34 & $0.27^{* *}$ & $0.31^{* *}$ & $0.27^{* *}$ & $0.24^{*}$ \\
& $(0.19)$ & $(0.10)$ & $(0.10)$ & $(0.09)$ & $(0.09)$ \\
Constant & $6.47^{* *}$ & $6.92^{* *}$ & $6.08^{* *}$ & $1.25^{* *}$ & $6.01^{* *}$ \\
& $(0.38)$ & $(0.23)$ & $(0.22)$ & $(0.21)$ & $(0.22)$ \\
Pseudo R & & & 0.21 & & \\
Observations & & & 19,999 & & \\
\hline
\end{tabular}

Note. Table entries are multinomial logit coefficients are (with their standard errors) in parentheses. The base outcome is voting for the FN. Negative coefficient values indicate an increase in the probability of voting for the FN, while positive coefficient values indicate an increase in the probability of voting for the other party in comparison. Reference group in social class is clerical and service staff.

${ }^{*} p<0.05{ }^{* *} p<0.01$.

Source: Enquête électorale française.
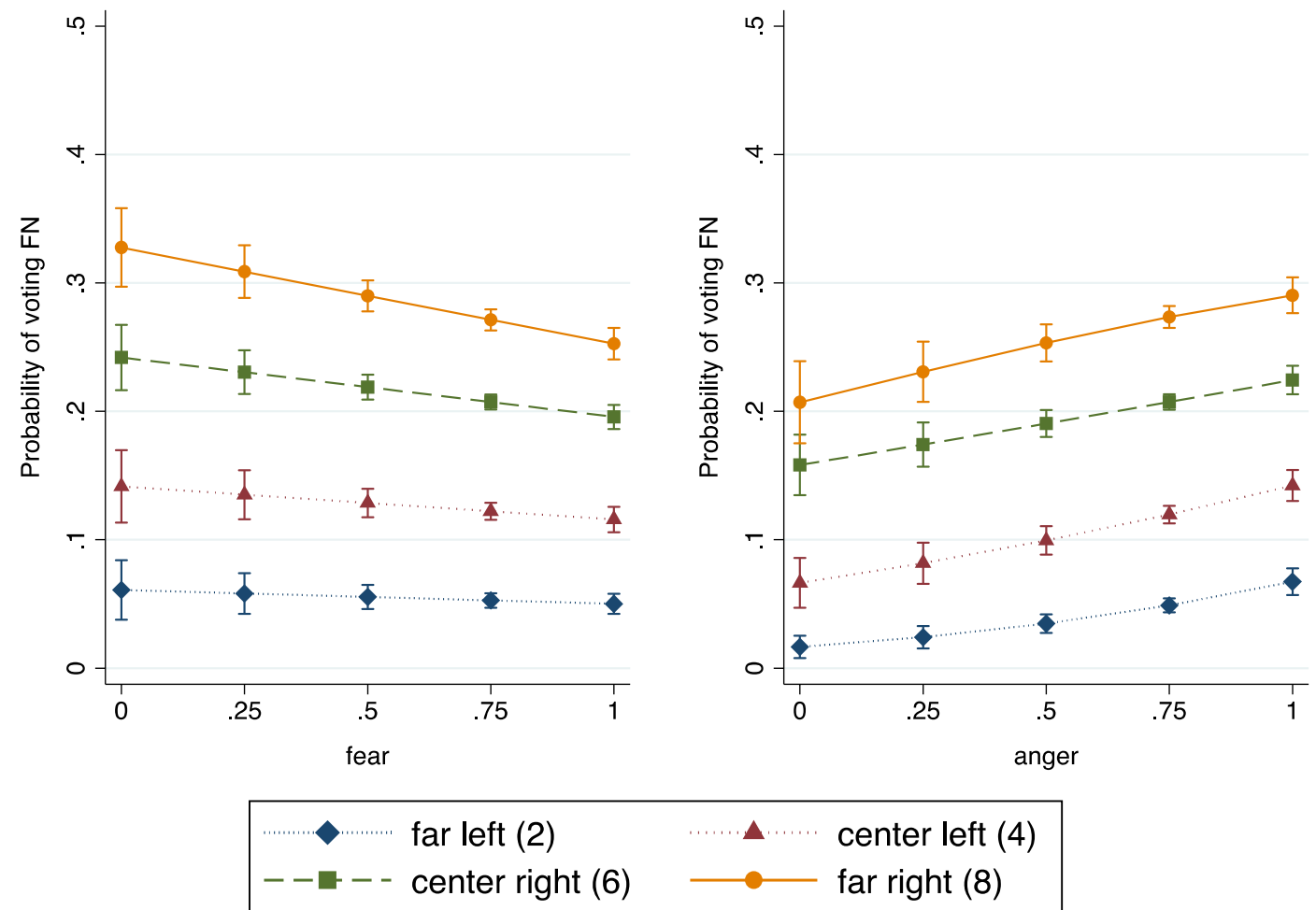

Figure A2. Interactions of fear and anger with ideology on the probability to vote for the FN controlling for ethnic intolerance attitudes. Source: Enquête électorale française [Colour figure can be viewed at wileyonlinelibrary.com] 

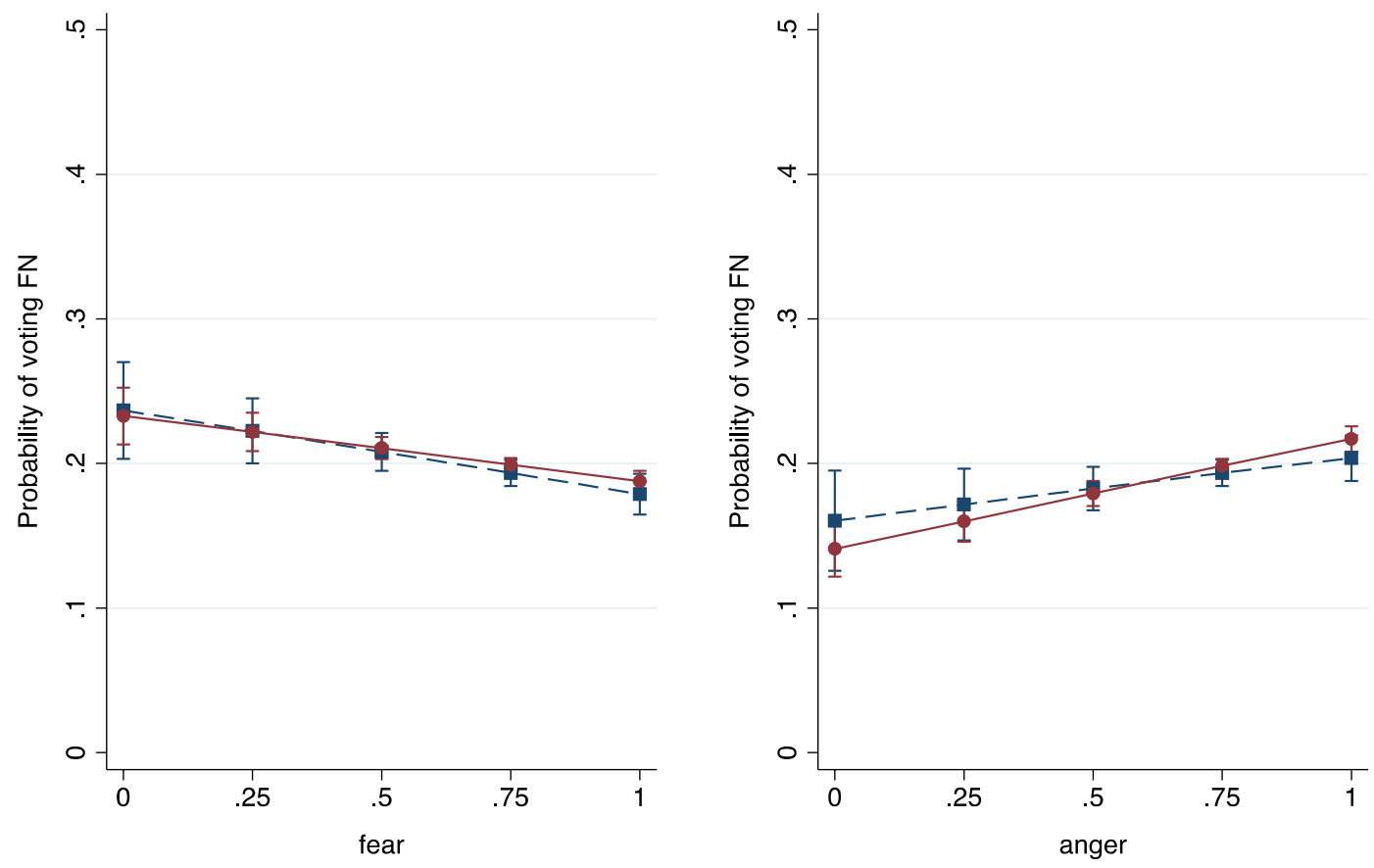

$--1--$ low authoritarianism $(0.25)$

high authoritarianism (0.75)

Figure A3. Interactions of fear and anger with authoritarianism on the probability to vote for the FN controlling for ethnic intolerance attitudes. Source: Enquête électorale française [Colour figure can be viewed at wileyonlinelibrary.com]

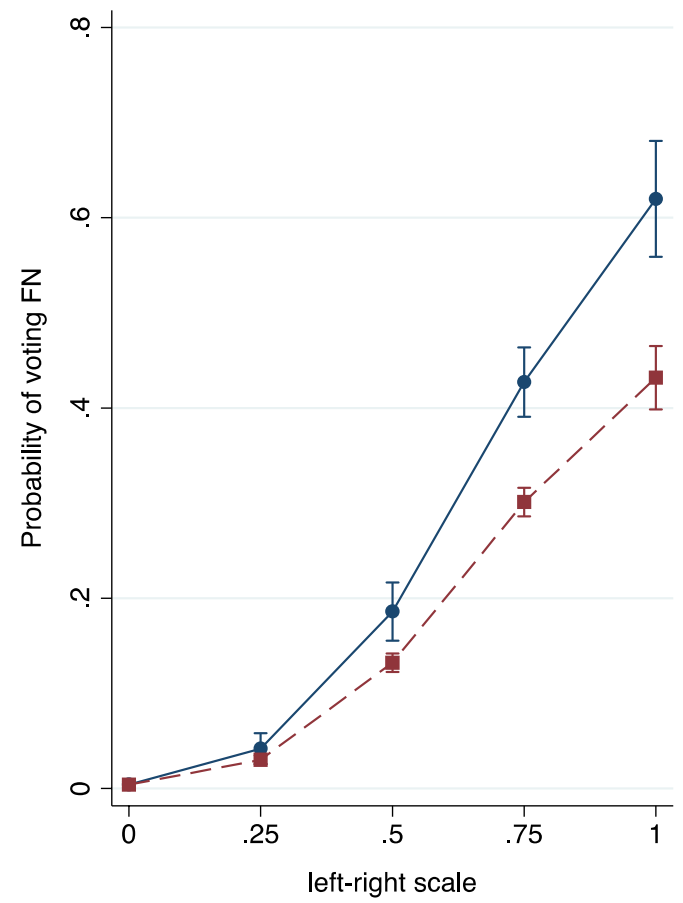

$\longrightarrow$ fear=0 $\quad-\rightarrow--$ fear $=1$

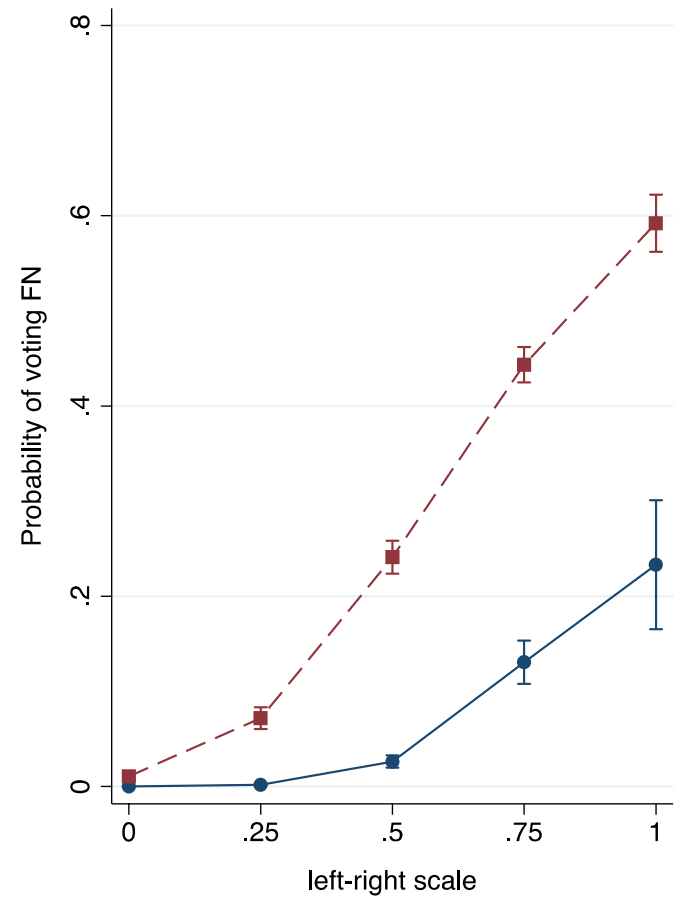

$\longrightarrow$ anger $=0 \quad----$ anger $=1$

Figure A4. The impact of fear and anger on the propensity to vote for the FN for different values of ideology. Source: Enquête électorale française [Colour figure can be viewed at wileyonlinelibrary.com] 


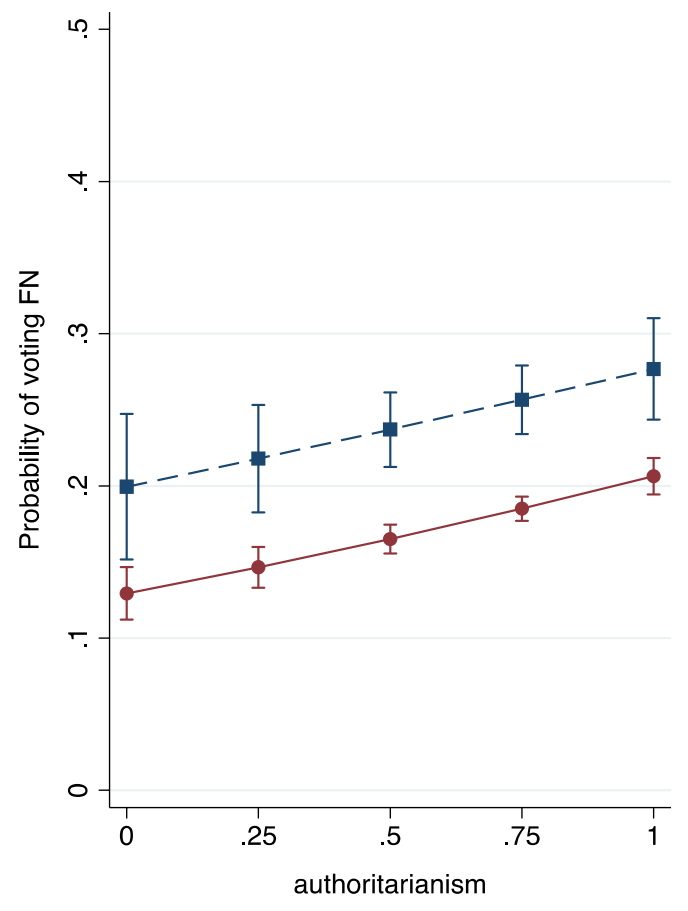

$-\rightarrow-$ fear $=0 \longrightarrow$ fear $=1$

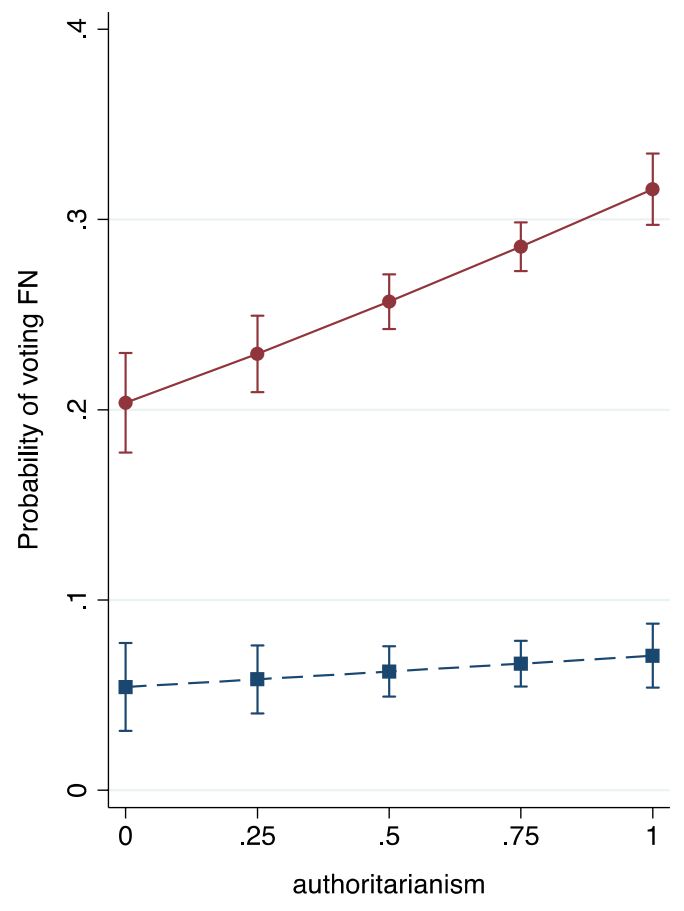

$-\neg--$ anger $=0 \quad \longrightarrow$ anger $=1$

Figure A5. The impact of fear and anger on the propensity to vote for the FN for different values of authoritarianism. Source: Enquête électorale français [Colour figure can be viewed at wileyonlinelibrary.com] 